
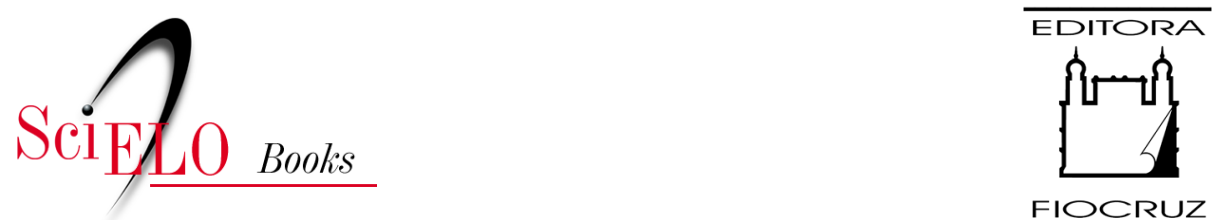

FIOCRUZ

\title{
5. Reformas do Seguro Social de Doença nos anos de 1990
}

\author{
Lígia Giovanella
}

\section{SciELO Books / SciELO Livros / SciELO Libros}

GIOVANELLA, L. Reformas do Seguro Social de Doença nos anos de 1990. In: Solidariedade ou Competição? Políticas e sistema de atenção à saúde na Alemanha [online]. Rio de Janeiro: Editora FIOCRUZ, 2001, pp. 185-245. ISBN: 978-65-5708-097-9.

http://doi.org/10.7476/9786557080979.0008.

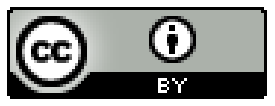

All the contents of this work, except where otherwise noted, is licensed under a Creative Commons Attribution 4.0 International license.

Todo o conteúdo deste trabalho, exceto quando houver ressalva, é publicado sob a licença Creative Commons Atribição 4.0.

Todo el contenido de esta obra, excepto donde se indique lo contrario, está bajo licencia de la licencia Creative Commons Reconocimento 4.0. 


\section{Reformas do Seguro Social de Doença nos Anos de 1990}

Capítulo elaborado em co-autoria com Hans-Ulrich Deppe, professor e diretor do Instituto de Sociologia Médica da Universidade J. W. Goethe, em Frankfurt.

Há mais de vinte anos, a questão da contenção de gastos tem caracterizado a política de saúde alemã. Desde os anos 70 , um dos pontos centrais da política de saúde tem sido a tentativa de estabilização das taxas de contribuição do Seguro Social de Doença. Uma política de subordinação dos gastos às receitas foi assumida: a elevação dos gastos não deveria ser superior à evolução dos salários dos contribuintes, de modo a evitar a majoração das taxas de contribuição e, em conseqüência, dos custos relacionados ao trabalho (BMAS, 1994; Alber, 1992).

O objetivo de estabilização das taxas de contribuição, justificado pela necessidade de evitar aumentos dos custos do trabalho e fortalecer a posição do capital alemão na competição internacional, foi explícito e reiteradamente assinalado nos documentos da coalizão governamental conservadora-liberal para reformulações setoriais (BMAS, 1994; CDU/CSU/FDP, 1996c). Desse modo, as pressões para redução dos custos sociais do trabalho têm tornado as políticas de saúde dependentes da política econômica e dos interesses empresariais de contenção de custos sociais. ${ }^{236}$

As coalizões governamentais - tanto a social/liberal como a democratacristã/liberal - promulgaram uma série de leis desde a segunda metade dos anos 70 , as quais elevaram sucessivamente a participação dos segurados nos custos, ainda que de forma moderada, e realizaram pequenas correçôes na estrutura do

236i Entretanto, a Alemanha apresenta excelente posiçāo como potência exportadora e alto nível positivo da balança comercial. Atualmente, é o segundo país em maior volume financeiro de exportaçóes, situando-se após os EUA e antes do Japão. Em 1995, por exemplo, as exportações globais foram de 5,254 trilhões de dólares; destes, $12 \%$ (625 bilhōes) foram exportados pelos EUA e 10\% (521 bilhōes de dólares) pela Alemanha. A metade das exportações da Alemanha vai para países da União Européia, o mesmo valendo para as importaçōes. A balança comercial entre EUA e Alemanha é positiva para esta última (Sozialpolitische Umschau, 213/1997 e 212/1997). 
seguro social de saúde (Gerlinger, Giovanella \& Michelsen, 1997).$^{237}$ Com isso, o sucesso das medidas de contenção foi de curta duração. Sucessivamente, a uma ligeira fase de redução ou estagnação das taxas de contribuição seguiu-se elevação, o que desencadeou nova lei de contenção. Este processo ficou sendo conhecido como 'espiral de leis de contenção' (Gráfico 6 e Quadro 3). Tais intervenções, mesmo que não tenham conseguido estabilizar as taxas de contribuição, fizeram com que a elevação dos gastos públicos com saúde fosse moderada. Os gastos do sistema de Seguro Social de Doença (GKV) mantiveram-se na faixa de $5 \%$ a $6 \%$ do PIB.

Um dos principais instrumentos das políticas de contenção de gastos no seguro social de doença alemão foi, até o final dos anos 80 , a fixação de tetos orçamentários, limitando os gastos por setor de atenção, de forma negociada, corporativa e conduzida pelo Estado. Negociação realizada principalmente por meio de uma câmara setorial, a Ação Concertada em Saúde, da qual participam os principais atores sociais, e por organizações intermediárias de concertação de interesses, as associações de médicos credenciados, de caixas e de outros prestadores.

A Ação Concertada em Saúde foi criada pela primeira lei de contenção importante, a 'Lei de Contenção do GKV' (Kostendämpfun GSGesetz), de 1977. Consiste em um fórum de aconselhamento, do qual fazem parte os mais importantes atores sociais e setoriais. ${ }^{238}$ Mais arena do que ator, dada a diversidade de atores e posições que o compōem, este fórum tem como funçāo analisar a situação, levantar problemas e formular recomendaçōes para a racionalizaçāo dos gastos e aumento da eficiência e efetividade do sistema de saúde. Estas recomendaçōes devem ser ponderadas quando da negociação de contratos entre as Caixas e prestadores de serviços. Nesse sentido, a Ação Concertada em Saúde pode ser considerada como um ator que participa da condução do sistema, cujas recomendações, deliberadas por consenso, são tomadas como orientaçōes para as negociações entre as diversas associaçōes. Conforme a legislação, na primeira reuniāo anual são feitas recomendações para a evolução de gastos setoriais ambulatoriais, hospitalares e medicamentos. Caso a Açāo Concertada não chegue a consenso, essas definiçōes são negociadas entre as Caixas e as respectivas

237 Para Borcher (1995), as políticas de contenção dos social-democratas dileririam das dos democrata-cristãos. Os social-democratas teriam maior preocupaçāo com a manutenção da proteção social. Suas políticas visariam mais a conter gastos do que a interferir na estrutura do sistema. Diferentemente, as políticas de contenção conservadoras afetariam a própria estrutura da proteção.

238 Esse tipo de fórum pode ser considerado a contrapartida setorial para a Ação Concertada, criada em 1967 por um governo de coalizão entre democratas-cristāos e social-democratas, com a participação de empregadores, sindicatos, burocratas e outras organizaçōes para discutir e negociar questōes mais gerais da economia (Offe, 1994). 
associaçōes de prestadores. Na reunião de outono devem ser discutidas recomendações para aumento da efetividadế e eficiência. ${ }^{239}$

$\mathrm{Na}$ Ação Concertada em Saúde tomam parte prestadores, seguradoras, empregadores, trabalhadores e governo. É composta por 75 membros representantes dos principais atores setoriais: Caixas (14), seguros privados (2), médicos e dentistas (11), hospitais (3), farmácias (3), indústria farmacêutica (4) empregadores (6), trabalhadores (6), governos estaduais e municipais (19) e outras associações (7). ${ }^{240}$

Nos últimos anos, a importância da Ação Concertada em Saúde na formulação da política tem diminuído, seja pela intervenção mais incisiva do legislador, seja pelo acirramento de diferenças de interesses, o que tem dificultado a produção de consenso e, em conseqüência, a possibilidade da formulação de recomendações.

A regulação de gastos e preços por intermédio das associaçōes ocorre ainda em mais dois outros níveis. Em um segundo nível ocorre negociação entre Caixas e prestadores. Além da negociação direta de preços e gastos entre as associações de Caixas e as associações dos diversos prestadores, são organizadas 'comissões conjuntas' em níveis federal e estadual, constituídas paritariamente pelas associações das Caixas e dos Médicos das Caixas, que conformam fóruns de negociação para a garantia de atenção ambulatorial necessária, suficiente e econômica. Em um terceiro nível, a regulação é interna às próprias associações de prestadores - em especial, àquelas dos médicos -, que exercem controle sobre seus filiados para que os acordos sejam cumpridos. ${ }^{241}$

Assim, uma série de atores sociais participa e influencia na formulação e implementação das políticas setoriais. Parte integrante do sistema, essa participação é regulada e tem base em uma forma de intermediaçāo entre Estado e Sociedade neocorporativa, modelo segundo o qual o Estado renuncia a medidas unilaterais e delega responsabilidades para a solução de conflitos e problemas de condução a organizações hierárquicas e de pertencimento obrigatório de fato ou de direito, atribuindo-lhes funçōes públicas e tornando-as participantes na formulação das opçōes políticas (Schmitter, 1974; Lehmbruch, 1996). Essa delegaçāo da tarefa pública de proteção aos interessados por meio da regulação da participação corporativa das partes envolvidas é uma das principais características do seguro social alemão. Não apenas trabalhadores e empregadores são responsabilizados

239 Em 1992, foi criado o Conselho de Experts para a Ação Concertada em Saúde, que deve elaborar uma avaliação anual a respeito do setor saúde. O Conselho é composto por sete membros independentes de notório saber na área da saúde ou economia, escolhidos pelo Ministro da Saúde com a participação dos membros da Ação Concertada.

210) Associações de deficientes, técnicos em saúde, prestadores de outros métodos terapêuticos, consumidores, $K u r$; beneficentes de cuidados e profissōes de cuidados (P/lege). Além dos membros com direito a voto, listados acima, tomam parte das reuniōes da Ação Concertada em Saúde: o ministro da Saúde - que as preside - e representantes de outros Ministérios.

241 Esses diversos níveis de intermediação de interesses orgânicos ao sistema de atençāo foram discutidos em maior detalhe no capítulo 3 . 
pela proteção, compondo os conselhos de administração dos diversos ramos do seguro social, como também é incentivada a organização corporativa dos prestadores, em especial, no caso da atenção ambulatorial, e delegada aos mesmos a responsabilidade de garantia da atenção.

Os demais instrumentos da contenção durante os anos 80 consistiram em ampliação parcial da competência das Caixas e repetidos acréscimos dos valores de co-pagamento desembolsados pelos segurados. O deslocamento de despesas com tratamento de saúde para os pacientes foi justificado com base na concepção de que um excesso de demanda, para além das necessidades médicas, seria uma das causas principais do aumento dos gastos setoriais. $O$ fortalecimento da 'autoresponsabilidade' por meio da transferência de despesas para o segurados seria, nessa concepção, medida efetiva de controle de gastos.

Por meio dessas diversas medidas, a evoluçāo dos gastos públicos foi moderada, entretanto, produziram redução de gastos por espaços de tempo curtos. Pode-se atribuir a breve duração dos efeitos de contenção, em primeiro lugar, à qualidade dos mecanismos selecionados, os quais não atingiram problemas estruturais do sistema de prestação de serviços. A definiçāo de tetos máximos por setor, um dos principais mecanismos introduzidos, cristalizou a distribuição de recursos entre os diversos setores de atençāo, sem levar em conta a necessidade de realocação entre setores nem a introdução de mecanismos adequados para maior integração do sistema de atenção - em particular, entre os setores ambulatorial e hospitalar - que possibilitasse uso mais parcimonioso dos recursos.

Entre outros, a reconhecida dominância dos prestadores na definição de preços e os falsos estímulos à expansão do volume de ações prestadas, como era o caso do sistema de remuneração ambulatorial por unidades de serviço, não foram enfrentados. As medidas relacionadas a problemas na organização da atenção foram, em geral, pontuais.

Os curtos sucessos das leis de contenção devèm-se também ao modo de implementação dos mecanismos aprovados. A implementação foi prejudicada em virtude de: baixa competência legal das Caixas para intervir na prestação de serviços; competição e conflitos entre as Caixas; reações dos prestadores, que rapidamente se adaptaram aos novos mecanismos e encontraram brechas e formas de fazer valer seus interesses, 'burlando', de certo modo, as medidas de contenção; e, por fim, insuficiência de pressão estatal no sistema de negociação (Reiners, 1993a; Stegmüller, 1996a). 
Gráfico 6 - Taxas de contribuição médias anuais do GKV. Região Ocidental

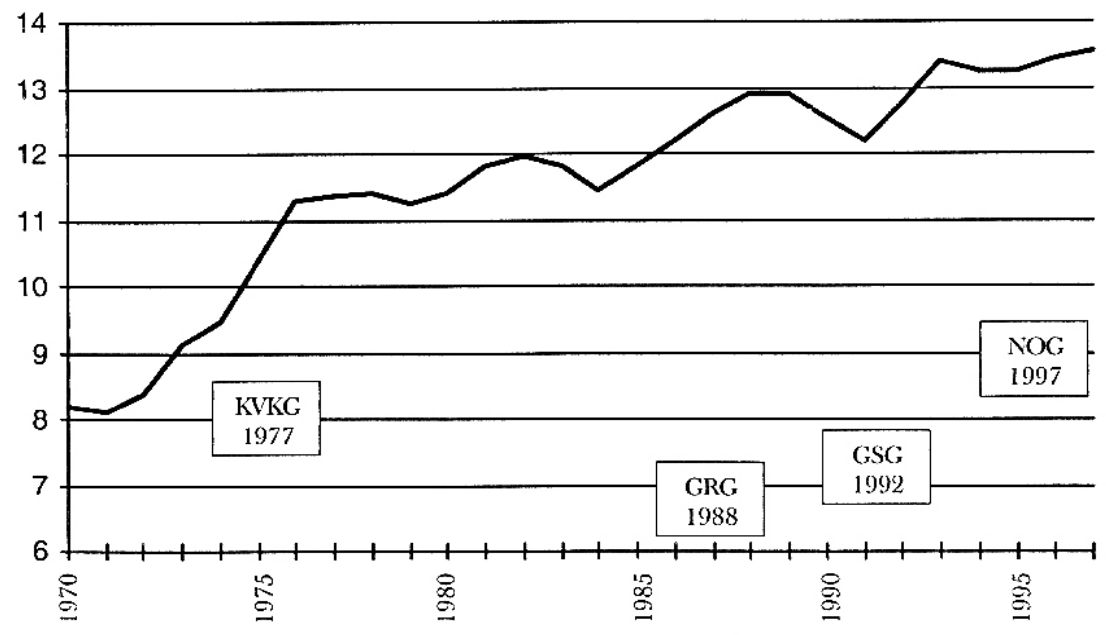

Fonte: SVR, 1994; BMG, 1995b. Para 1995 c 1996, BMG, 1996. Para 1997, foi utilizada a taxa de janciro de 1998; BMG, 1998b.

Este foi o ritmo da política de saúde até o final dos anos 80 , quando a coalizão conservadora-liberal iniciou processo de reforma que consistiu, até o final dos anos 90, de três etapas: 1) Lei da Reforma da Saúde (Gesundheitsreformgesetz - GRG), de 1988; 2) Lei da Estrutura da Saúde (Gesundheitsstrukturgesetz $G S G$ ), de 1992; 3) Leis de Reordenação do GKV - 1. und 2 (GKV NeuordnunGSGesetz - NOG), de 1997.212

Importante corte nesse ritmo foi marcado pela Lei da Estrutura da Saúde (Gesundheitsstrukturgesetz-GSG) de 1992. A lei resultou de uma 'grande coalizão' setorial que uniu democrata-cristãos e social-democratas, tendo sido promulgada sem a participação do partido liberal (FDP). A orientaçāo da política contencionista foi alterada com essa legislação, a qual, além de incluir componentes tradicionais de contenção, mudou o sistema de incentivos à prestação, provocou impacto nos interesses dos prestadores e modificou um dos elementos característicos da organização da proteçāo segundo o modelo de seguro social, que era a adscrição diferenciada compulsória dos trabalhadores conforme sua inserção na produção, possibilitando a liberdade de escolha da Caixa de Doença para a maioria dos contribuintes.

242 Esses são os anos de promulgação das leis que entraram $\mathrm{cm}$ vigor $\mathrm{em}$ janeiro dos anos subseqüentes - 1989 e 1993 -; por isso, aparecem, por vezes, datas diferentes no texto, dependendo da referência à data da vigência ou da promulgação da lei. 
Quadro 4-Cronologia das Principais Leis de Contenção Promulgadas

\begin{tabular}{|c|c|}
\hline \multicolumn{2}{|r|}{ Principais Leis de Contenção } \\
\hline 1972 & Lci do Financiamento Hospitalar (Krankenhaus- FinanzierunGSGesetz) \\
\hline 1977 & Lei de Contenção do GKV ( GKV-KostcndämpfunGSGesetz - KVKG) \\
\hline 1981 & $\begin{array}{l}\text { Lei de Contenção Hospitalar } \\
\text { (Krankenhaus-KostendämpfunGSGesetz - KHKG) }\end{array}$ \\
\hline 1981 & $\begin{array}{l}\text { Lci Complementar à Contenção no GKV } \\
\text { (Kostcndämpfungs-ErgänzunGSGcsetz --KVEG) }\end{array}$ \\
\hline 1984 & $\begin{array}{l}\text { Lci de Reordenação Hospitalar } \\
\text { (Krankcnhaus-NcuordnunGSGesetz - KHNG) }\end{array}$ \\
\hline 1988 & Lei da Reforma da Saúde (Gesundhcitsreformgesctz - GRG) \\
\hline 1992 & Lei da Estrutura da Saúde (Gesundheitsstrukturgesetz - GSG) \\
\hline 1996 & Lei de Alívio da Contribuições (BcitragsentlastunGSGesctz) \\
\hline 1997 & $\begin{array}{l}\text { Leis de Reordenação do GKV } \\
\text { (1. und 2. GKV-NeuordnunGSGesetz - NOG) }\end{array}$ \\
\hline
\end{tabular}

Tal processo crescente de mudanças legislativas, 'a reforma da saúde e suas três ctapas', é discutido a seguir. Inicialmente são apresentadas, de modo sucinto, as duas primeiras etapas - a Lei da Reforma da Saúde (GRG) e a Lei da Estrutura da Saúde (GSG), para então analisar-se, em maior detalhe, a 'terceira etapa', Leis de Reordenação do GKV (NOG), promulgadas em 1997. São apresentadas as propostas dos principais atores sociais, discutidas suas posiçōes e analisadas as medidas aprovadas na lei da 'terceira etapa'.

Distinta fase na política de saúde alemã tem início, ao final de 1998, quando uma nova coalizão governamental, composta pelos partidos social-democrata e verde, ${ }^{243}$ assumiu o poder Logo após a sua vitória eleitoral, foi aprovada legislação preliminar, a Lei da Solidariedade no GKV ( $G K V$-Solidaritätsgesetz), suspendendo as mais importantes restrições introduzidas com a 'terceira etapa' e definindo regulamentaçōes de curto prazo. De modo simultâneo, iniciou-se processo de discussão para nova reforma, tendo sido aprovada em dezembro de 1999 a Lei da Reforma do GKV 2000 (GKV-Gesundheitsreformgesetz 2000), redirecionando o processo de reformas da proteção social alemā. ${ }^{244}$

2 t3 SPD (Sozialdemokratische Partei Deutschland), partido social-democrata; partido verde (Grünen/Bündis 90 ).

24. O presente estudo tem como foco o processo de reformulação impulsionado pela coalizão conservadora-liberal e foi realizado no período de 1996-1998. Desse modo, a referência a esta legislação mais recente será breve. 


\section{Lei da Reforma da Saúde (Gesundheitspeformgesetz-GRG)}

A decisão a respeito da necessidade de reforma do Seguro Social de Doença alemão não foi imediata à posse da coalizão formada em 1982 por democratacristãos-liberais - CDU/CSU e FDP. ${ }^{245}$ Apenas no outono de 1985, sob a pressão de novos aumentos das taxas de contribuição, a coalizão governamental resolveu encaminhar uma discussão que visava a desenvolver uma concepção de reforma capaz de estabilizar por longo prazo as finanças do Seguro Social de Doença (Gesetzliche Krankenversicherung - GKV)-, cuja legislação deveria ser promulgada na próxima legislatura (Perschke-Hartmann, 1992). ${ }^{246}$

Em janeiro de 1989, entrou em vigor a Lei da Reforma da Saúde (GRG), a primeira etapa da reforma que esta coalizão governamental buscava implementar. ${ }^{247}$ Tendo como prioridade máxima a estabilidade das taxas de contribuição, mediante essa lei, pretendia-se aliviar o GKV em 14,5 bilhões de marcos anuais. Metade dessas economias deveria redundar em redução das taxas de contribuição dos segurados e a outra metade seria utilizada na ampliação e melhoria de benefícios, em particular os cuidados de longa duração para pacientes com dependência/necessidade severa (Eberle, 1998).

Por meio da Lei da Reforma da Saúde (GRG), reorganizou-se o direito sanitário. Toda a legislação social foi agrupada e sistematicamente reordenada de forma a compor o Livro V do Código Social; daí a sua denominação.

A Lei da Reforma da Saúde - lei proposta e aprovada pela coalizão governamental conservadora-liberal - adotava como motes: 'redefinir a solidariedade', 'fortalecer a auto-responsabilidade' e 'criar mais eficiência' (Blüm, 1988). A maioria das medidas aprovadas permaneceu na tradição das leis de contenção, restringindo gastos. $O$ ponto central esteve na reformulaçăo da cesta de serviços cobertos mediante determinados cortes em ações curativas, ${ }^{248}$ aumento de co-pagamento e favorecimento de açōes preventivas e de promoção da saúde. Foram incluídas açōes tidas como necessárias e não contempladas até então, em especial, as de

245 CDU (Christliche Demokratische Union), partido democrata-cristão; CSU (Christliche Soziale Union), partido social cristão (menos importante, é um partido regional da Bavária/Munique); FDP (Freidemokratische Partes), partido liberal.

246 Dez teses foram então lançadas por Norbert Blüm, ministro do Trabalho e Ordem Social responsável pelo seguro social de doença na época, e rejeitadas pela Ação Concertada em Saúde.

247 Esta lei foi tida inicialmente como a 'primeira' reforma da saúde 'de fato'. A diversidade e o embricamento de interesses setoriais tinham sido, até então, ponderados como impeditivos de reforma (BMAS, 1994).

218 Restrições ocorreram na forma da instituição de restituição de apenas $50 \%$ das despesas com próteses dentárias, bem como a criação de subsídios fixos para óculos e aparelhos de audiçāo. 
promoção, um dos aspectos considerado dos mais positivos na Lei, e as preventivas, como profilaxia dentária para crianças e-jovens, screening para doenças cardiovasculares e renais para adultos. Cuidados de longa duração para pacientes com perda de autonomia e grau de dependência severo passaram a ser responsabilidade das Caixas. ${ }^{249}$

$\mathrm{Na}$ assistência farmacêutica, com o intuito de controlar gastos com medicamentos, estabeleceu-se um sistema de definição de preços máximos (Festbetrag), negociados entre Caixas, indústria farmacêutica e farmácias, a serem pagos pelas Caixas às farmácias. Segundo esta sistemática ainda vigente, se o preço do medicamento for mais elevado do que o valor máximo fixado, o médico deve informar ao paciente que está receitando medicamento de preço superior e o segurado arcará com a diferença; entretanto, o preço da maioria dos medicamentos se mantém nos limites fixados.

A lei reforçou ainda a competência das Caixas no controle dos serviços prestados por médicos e hospitais e a condução negociada da atenção, definindo novos campos para decisōes homogêneas e conjuntas das Caixas. A possibilidade de intervenção das Caixas nas provas de economicidade realizadas por médicos e hospitais foi fortalecida. O Serviço Médico das Caixas foi reestruturado, dando direito a examinar o tipo e a extensão das açōes médico-sanitárias prescritas e ou realizadas, com o objetivo de conter a expansão do volume de açōes prestadas e controlar fraudes. Foram ainda ampliadas as competências das instâncias conjuntas compostas pelas Caixas e prestadores na definição de normas de qualidade. Todavia, ao regular estritamente as relações entre as Caixas e destas com os prestadores, a lei significou diminuição da autoridade própria de parte das organizaçóes corporativas da administraçāo autônoma; em particular, o poder das Associaçōes de Médicos.

A Lei da Reforma da Saúde foi criticada pela maioria dos atores sociais. Os sindicatos consideraram-na anti-social; os médicos, limite à liberdade de conduta e os empresários, ameaça à indústria farmacêutica e à posição da Alemanha na concorrência internacional. A aprovação da lei apresentada pelo ministro do Trabalho e Ordem Social no Parlamento (Bundestag) tornou-se possível em razāo dos aumentos ocorridos nas taxas de contribuição, das ameaças de imposição legal de medidas ainda mais restritivas, assim como da introdução de pequenas alteraçōes durante o processo de discussão no Parlamento (Blanke \& Kania, 1996).

Embora os preços de medicamentos tenham sido fixados (Festbetrag) e os produtores tenham ajustado seus preços ao valor estabelecido, considera-se que as perdas da indústria farmacêutica foram compensadas pelos medicamentos não incluídos no sistema ${ }^{250}$ e que tiveram seus preços majorados, não tendo sido pos-

24. Estes encargos vinham sendo financiados com recursos fiscais dos estados e municípios.

250) Por influência principalmente da indústria farmacêutica e do partido liberal, apenas $60 \%$ dos medicamentos foram incluídos no sistema; anteriormente fora proposta a inclusão de $80 \%$ (Perschke-Hartmann, 1992). 
sível controlar esse tipo de gastos. Os segurados, por sua vez, antecipando-se às restriçōes e aumentos do co-pagamento, compraram óculos e completaram suas próteses antes de a lei vigorar, o que produziu elevação desses gastos em 1988 (tabela 22). Assim, no ano seguinte, os resultados da contenção já estavam quase dissipados (Eberle, 1998; Reiners, 1993a).

Ainda que tenha sido ineficaz na contenção a médio prazo, a lei produziu imediatamente o controle dos gastos do GKV, que foram inferiores em 1989 aos do ano anterior, possibilitando a redução da taxa média de contribuição em 0,4 pontos percentuais em 1990, ano em que o valor alcançado foi de $12,53 \%$, e de mais 0,3 pontos no ano seguinte, ficando em $12,2 \%$ a taxa média de contribuição em 1991.

Tabela 21 -Variação anual em \% dos gastos do GKV em setores de atenção selecionados, dos salários médios e dos preços em geral.* Alemanha (Região Ocidental) - 1987-1997

\begin{tabular}{|c|c|c|c|c|c|c|c|c|c|c|c|}
\hline Atenção & 1987 & 1988 & 1989 & 1990 & 1991 & 1992 & 1993 & 1994 & 1995 & 1996 & 1997 \\
\hline $\begin{array}{l}\text { Ambula- } \\
\text { torial }\end{array}$ & 3,3 & 3,3 & 4,6 & 7,6 & 9,7 & 8,2 & 3,3 & 4,0 & 3,6 & 3,0 & 2,1 \\
\hline Hospitalar & 4,6 & 0,7 & 3,4 & 9,3 & 10,2 & 9,8 & 5,6 & 7,7 & 3,8 & $-0,3$ & 2,3 \\
\hline $\begin{array}{l}\text { Odonto- } \\
\text { lógica }\end{array}$ & 2,9 & 4,4 & 0,0 & 6,2 & 11,7 & 11,3 & 2,5 & 4,7 & 1,3 & 7,8 & 1,6 \\
\hline $\begin{array}{l}\text { Próteses } \\
\text { Dent. }\end{array}$ & $-8,9$ & 53,6 & $-49,6$ & $-0,4$ & 16,0 & 21,9 & $-28,2$ & 15,5 & 7,1 & 11,0 & 2,2 \\
\hline $\begin{array}{l}\text { Farma- } \\
\text { cĉutica }\end{array}$ & 7,2 & 8,2 & $-1,1$ & 8,0 & 12,1 & 10,6 & $-19,5$ & 4,9 & 7,4 & 6,9 & $-3,9$ \\
\hline $\begin{array}{l}\text { Outros } \\
\text { Mcios** }\end{array}$ & 8,7 & 13,5 & 12,1 & 7,7 & 15,0 & 12,0 & 1,1 & 13,4 & 10,0 & 9,2 & $-3,8$ \\
\hline $\begin{array}{l}\text { Auxílio- } \\
\text { Doença }\end{array}$ & 7,5 & 5,3 & $-0,1$ & 13,2 & 16,7 & 7,9 & $-0,9$ & 7,6 & 14,2 & $-2,0$ & $-21,2$ \\
\hline $\begin{array}{l}\text { Total } \\
\text { Ações }\end{array}$ & 4,3 & 7,7 & $-3,8$ & 8,9 & 13,0 & 10,7 & $-1,1$ & 7,5 & 4,9 & 3,2 & $-1,9$ \\
\hline $\begin{array}{l}\text { Salário } \\
\text { Médio }^{251}\end{array}$ & 3,4 & 2,7 & 2,7 & 4,6 & 6,2 & 5,7 & 3,8 & 2,0 & 3,6 & $\# 1,9$ & - \\
\hline Preços & 0,1 & 1,1 & 2,9 & 2,7 & 3,7 & 4,1 & 3,7 & 2,8 & 1,7 & ${ }^{\#} 1,3$ & - \\
\hline
\end{tabular}

*Preços da cesta de uma família de quatro pessoas com renda média. **Outros meios: inclui Heil-und Hilfsmittel. \#Diferença em relaçāo ao primeiro semestre do ano anterior. Fonte: BMG, 1996; para os anos de 1987 a 1989, cálculos próprios; para 1996 e 1997 (resultados preliminares), http://www.bmgesundheit.de; para preços e salários, Schäfer, 1996a.

251 A confrontação com os salários, mais do que com as taxas de contribuição, possibilita avaliação da evolução de gastos em comparação com a das receitas potenciais. Embora estes aumentos não se refiram aos salários de contribuição, permitem comparação aproximada. 
No entanto, o GKV apresentou novo déficit ainda em 1991. A redução das taxas de contribuição por conta do superávit do ano anterior e mais o crescimento de gastos da ordem de $10 \%$, contra elevação das receitas de apenas $5 \%$, fez com que o ano de 1991 fosse fechado com importante déficit, esvanecendo-se a efeito de contençāo.

Estes efeitos decorreram também da unificação alemã. A extensão do seguro social de doença para a Região Oriental, a partir de janeiro de 1991, teve expressivas conseqüências financeiras apenas para o GKV. Tanto recursos fiscais como de contribuições foram aplicados na Região Oriental para adequação dos sistemas de proteção e atenção ao modelo ocidental. Embora preços e honorários proporcionalmente mais baixos tenham sido acordados para a Região Oriental, em correspondência ao potencial mais baixo de arrecadação da região por conta do nível inferior de salários, a oferta e a utilização dos serviços e, em conseqüência, a evolução de gastos aproximaram-se rapidamente daquelas da Região Ocidental.

Quadro 5 - Receitas, despesas, saldo anual* e taxas médias anuais de contribuição** do Seguro Social de Doença. Alemanha, Região Ocidental - 1988-1997; Região Oriental - 1991-1997

\begin{tabular}{|rrrrrrrr|}
\hline Ano & Receitas & Despesas & $\begin{array}{c}\text { Saldo } \\
\text { Oeste }\end{array}$ & $\begin{array}{r}\text { Saldo } \\
\text { Leste }\end{array}$ & $\begin{array}{r}\text { Saldo } \\
\text { Total }\end{array}$ & $\begin{array}{c}\text { Taxa } \\
\text { Mćdia } \\
\text { Oeste }\end{array}$ & $\begin{array}{r}\text { Taxa } \\
\text { Média } \\
\text { Leste }\end{array}$ \\
\hline 1988 & 132.639 & 134.376 & -1.737 & & & 12,90 & \\
1989 & 139.682 & 129.927 & 9.755 & & & 12,90 & \\
1990 & 147.753 & 141.654 & 6.099 & & & 12,53 & \\
1991 & 154.221 & 159.814 & -5.593 & 2.773 & -2.820 & 12,20 & 12,80 \\
1992 & 167.778 & 176.876 & -9.098 & -256 & -9.354 & 12,74 & 12,61 \\
1993 & 184.421 & 175.362 & 9.059 & 1.355 & 10.414 & 13,41 & 12,62 \\
1994 & 194.181 & 192.120 & 2.061 & 116 & 2.177 & 13,23 & 12,95 \\
1995 & 212.233 & 217.352 & -5.119 & -1.836 & -6.955 & 13,24 & 12,82 \\
1996 & 219.700 & 224.340 & -4.640 & -2.140 & -6.780 & 13,43 & 13,28 \\
1997 & 220.750 & 219.350 & 1.400 & -300 & 1.100 & $* * * 13,56$ & $* * * 13,95$ \\
\hline
\end{tabular}

*Em milhões de marcos conrentes. **Em \% dos salários de contribuiçāo. ***Janeiro de 1998. Fonte: BMG, 1996 T.10.9 e T.10.11; para 1996 e 1997, http://www.bmgesundheit.de em 11.06.98.

Os efeitos de contenção da Lei da Reforma da Saúde (GRG) duraram apenas dois anos. Em 1991, o déficit da Região Ocidental alcançou 5,6 bilhōes de marcos e, em 1992, o GKV ostentou o maior déficit nominal de sua história recente: mais de 9 bilhōes de marcos (Quadro 5). ${ }^{252}$

252 Não é possível ampliar as consideraçooses a respeito do nível de déficits ao longo da história, pois maiores déficits têm a ver também com relutância em aumentar taxas de contribuiçāo. Em anos anteriores, acréscimos de gastos poderiam ter sido cobertos por elevações nas taxas de contribuiçāo, reduzindo-se os déficits. 


\section{Lei da Estrutura da Saúde (Gesundheitsstrukturgesetz - GSG)}

Logo depois da entrada em vigor da Lei da Reforma da Saúde (GRG) já se avaliava que os principais problemas de organizaçāo, financiamento e prestação de serviços do GKV haviam permanecido sem soluçāo (Wanek, 1994). Ao início de 1992, a coalizão governamental apresentou pacote de contenção após aumento das taxas de contribuição em decorrência do alto déficit do GKV. Após duras críticas, em contexto econômico adverso - o boom da unificação havia se dissipado e o desemprego era crescente - e de pressão acentuada para redução dos custos sociais do trabalho, evitando minar sua política de modernização voltada para a competição internacional (Bieling, 1996), a coalizão governamental foi obrigada a negociar. Uma 'grande coalizão específica ${ }^{9253}$ foi constituída e, em poucas semanas, formulada a Lei da Estrutura da Saúde (Gesundheitsstrukturgesetz - GSG). Resultado do compromisso com a oposição social-democrata, a lei foi votada e aprovada quase sem alterações, em menos de dois meses; mesmo contra a resistência de vários grupos (Bieback, 1993).

A lei incluiu uma série de componentes das políticas de contenção tradicionais, de acordo com o objetivo estrito de estabilização das taxas de contribuiçăo. Adotou a orçamentação com definição de tetos máximos prefixados para os principais setores de atenção (cuidados hospitalares, médico-ambulatoriais e dentários, prescrição de medicamentos e outros meios terapêuticos), acoplados à evolução das receitas de contribuição. ${ }^{254}$ As taxas de co-pagamento para internações hospitalares, medicamentos e próteses dentárias foram majoradas (Graf von der Schulenburg, 1994; Stegmüller, 1993 e 1996a; Braun, 1995).

$\mathrm{O}$ acordo entre social-democratas e democrata-cristãos, todavia, possibilitou a aprovação de lei abrangente, a qual se diferencia das leis de contenção anteriores por componentes 'estruturais' relativos à organização da proteção à saúde, e por incluir medidas com potencialidade de impacto na estrutura de atenção e interesses dos prestadores de serviços - indústria farmacêutica, médicos, hospitais - por estímulos diferenciados para a prestação.

A Lei da Estrutura da Saúde (GSG), segunda etapa da reforma, modificou regras de organização do GKV: ampliou a liberdade de escolha da Caixa por parte dos segurados e criou mecanismo de compensação da estrutura de riscos entre as Caixas, visando a estabelecer a competição entre elas; mecanismos estes discutidos em detalhe na próxima seção.

253 Denomina-se grande coalizão, exemplo máximo da sociedade do compromisso e da concertação, a aliança de social-democratas e democrata-cristāos, as duas grandes forças políticas/partidos da Alemanha.

2.54 Com a GSG, pela primeira vez, todos os setores de atenção tiveram tetos orçamentários máximos fixados (Waneck \& Stegmüller, 1993). 
As principais medidas que alteram os incentivos à prestação referem-se à assistência farmacêutica e ao setor hospitalar. A lei previa a elaboraçăo de 'lista positiva' com todos os medicamentos passíveis de pagamento pelas Caixas. Com a elaboração da lista, todo os medicamentos de efeitos restritos e duvidosos existentes no mercado seriam excluídos do pagamento, o que, afora a contenção dos custos, melhoraria a qualidade da assistência farmacêutica prestada, evitando o consumo de medicamentos inúteis ou de efeito duvidoso. ${ }^{25.5}$ A lista, entretanto, não foi implementada por pressão da indústria farmacêutica. ${ }^{256}$ Esta lista, inquestionável instrumento para a melhoria da qualidade da assistência farmacêutica prestada ${ }^{257}$ pelas Caixas e com grande potencial de economia, ${ }^{258}$ foi abolida, antes mesmo de sua elaboração, mediante projeto de lei enviado pela coalizāo governamental ao Parlamento.

Paralelamente à definiçāo de teto orçamentário para a assistência farmacêutica foram previstas sanções financeiras para os médicos. Caso ultrapassassem o limite de gastos previsto para medicamentos, teriam de deduzir de seus honorários valor correspondente. As sançōes e tetos, contudo, foram apenas parcialmente implementados. ${ }^{259}$

$\mathrm{Na}$ área hospitalar, a GSG redirecionou incentivos ao modificar o sistema de pagamento hospitalar. $\mathrm{O}$ sistema de remuneração por diárias uniformes por hospital, calculadas de modo a cobrir todos os custos do hospital, até então vigente, foi substituído por sistema misto que inclui pagamentos prospectivos por casos tratados e diárias por tipo de enfermaria. Entre outras medidas, buscou-se ainda maior articulação da atenção hospitalar e ambulatorial por meio da adoçāo de pagamentos para atenção pré e pós-hospitalar, cirurgias ambulatoriais e planejamento para equipamentos de grande porte. Com tais medidas, objetivava-se maior eficiên-

255 Uma lista negativa, como as restriçōes acima enumeradas, arrolaria apenas os medicamentos năo passíveis de remuneração. A lista positiva é mais adequada, pois cada inclusão requer a análise do medicamento citado. No caso de lista negativa, cada nova especialidade introduzida no mercado é passível de prescrição e de pagamento pelas Caixas.

256 A indústria larmacêutica, na Alemanha, é potente. A indústria química e o setor de máquinas e equipamentos constituem as especializaçōes tradicionais da indústria alemã (Teixeira, 1993).

2.57 Muitos destes medicamentos são receitados no Brasil, por exemplo: combinações de corticóides e antibióticos tópicos, medicamentos contra hemorróidas, colagogos, combinaçōes de antiácidos, expectorantes etc.

$2.58 \mathrm{Em}$ 1995, os gastos com esse tipo de medicamento foram estimados em 7 bilhōes de marcos (Schwabe \& Paffrath, 1996).

259 A ameaça de sanção surtiu efeito imediato. Em seis meses, os gastos com medicamentos hạviam sido reduzidos em $20 \%$. Contudo, por afetar suas vendas dentro da Alemanha, as pressões da indústria farmacêutica foram tantas e tão fortes que a medida foi abolida, embora tivesse demonstrado ser positiva (Evans, 1996). O autor utiliza o exemplo da política de contenção de gastos com medicamentos na Alemanha para inferir que uma medida de contenção de gastos provavelmente está funcionando, controlando gastos, quando é descrita como efetiva pelos responsáveis últimos do pagamento das contas e é condenada como inefetiva por aqueles cujas rendas serão contidas (Evans, 1996:96). 
cia e qualidade da assistência - ao evitar a desnecessária duplicação de exames para o mesmo paciente por níveis ambulatorial e hospitalar -, reduzir dias de internação e oferta desnecessária de equipamentos.

O setor ambulatorial foi alvo de claras medidas restritivas, por intermédio da GSG, pela primeira vez no período pós-guerra (Reiners, 1993). A GSG alterou tanto o volume quanto o sistema de honorários e sua distribuição entre os médicos, produzindo repercussōes negativas na renda dos médicos. Além da definição estrita de teto máximo de gastos, os honorários para ações prestadas por médicos generalistas foram reajustados de forma diferenciada, criando-se remuneração básica por caso e tendo sido aprazada para 1995 a definição de complexos de açōes, alterando o sistema até então vigente de pagamentos por unidades de serviços. Nova norma para a admissão foi definida, restringindo a admissão de credenciamentos médicos, como compensação ao maior controle dos rendimentos imposto pela lei àqueles já credenciados (Hungeling, 1993). ${ }^{260}$

As medidas da GSG mais importantes dizem respeito a regras de organização do GKV, liberdade de escolha das Caixas pelos contribuintes e criação de compensação financeira entre as Caixas referente à estrutura de riscos de seus segurados, discutidas a seguir.

\section{Liberdade dos segurados para escolha da Caixa}

A Lei da Estrutura da Saúde (GSG) faz jus à denominação por alterar uma das características da organização do seguro social. Até então, os contribuintes deveriam afiliar-se obrigatoriamente a certo tipo de Caixa conforme sua inserção na produção. A GSG possibilitou a liberdade de escolha da Caixa para a grande maioria dos contribuintes. A tradicional adscrição com base no status do segurado foi quase totalmente abolida.

Desde janeiro de 1996, novos segurados podem escolher entre a Caixa Local da regiāo em que moram ou trabalham e as Caixas Substitutas, possibilidade anteriormente restrita aos empregados. Caixas de Corporações e de Empresas decidem pela abertura ou não para admissão de segurados fora de seu círculo estrito de trabalhadores. As Caixas Rurais e a dos Mineiros e Marítimos permanecem com a clientela tradicional legalmente adscrita. A partir de 1997, passou a vigorar a possibilidade de troca de Caixa para segurados antigos. Por este meio, a maior parte dos segurados (85\%) passou a desfrutar da liberdade de escolha da Caixa e da possibilidade de trocá-la anualmente, se assim o desejar.

260 As alteraçōes introduzidas pela lei referentes ao setor hospitalar e ambulatorial foram detalhadas no capítulo 3. 
Semelhante ampliação da liberdade de afiliação dos segurados representa importante alteração da legislação até então vigente. Com este mecanismo, rompe-se a histórica obrigatoriedade de adscrição dos segurados a determinadas Caixas conforme sua ocupação, eliminando-se as desigualdades de tratamento no que concerne à escolha de Caixa.

Todavia, a liberdade de escolha das Caixas pelos segurados objetivou ampliar a competição entre as Caixas. $\mathrm{Na}$ concepção da coalizão governamental, a implementação da liberdade de escolha obrigaria as Caixas a conformar oferta mais atrativa, eficiente e econômica em razão da concorrência por segurados (BMAS, 1994). Todas as Caixas, para permanecerem atraentes a seus membros e seduzir novos, devem mostrar vantagens comparativas.

\section{Compensação financeira da estrutura de riscos}

Instaurou-se, ao mesmo tempo, procedimento de redistribuição financeira entre as Caixas para a compensaçāo da estrutura de riscos do coletivo de segurados de cada Caixa (Risikostrukturausgleich - RSA). Desse modo, a Lei da Estrutura da Saúde (GSG) criou condições mais adequadas à introdução da competição no interior do sistema. A compensação da estrutura de riscos teve por meta evitar a competição predatória.

As Caixas sempre tiveram taxas de contribuição distintas em decorrência das diferenças de estrutura de riscos de seus segurados relativas a sexo, idade, renda, número de dependentes, morbidade, proporção de aposentados etc. As transferências financeiras buscam compensar essas diferenças e colocar as Caixas em igualdade de oportunidade na competição por segurados agora com livre escotha. Com a introdução do mecanismo, busca-se possibilitar a comparação entre taxas de contribuição, considerado o principal sinalizador de preços, de diversas Caixas pelos contribuintes. A compensação financeira da estrutura de riscos inclui renda dos segurados, número de dependentes, idade, sexo e proporção de aposentados por incapacidade. ${ }^{261}$

261 Considera-se também a proporção de contribuintes com direito ao auxílio-doença, critério relacionado especialmente a segurados voluntários. 
Quadro 6 - Principais medidas da Lei da Reforma da Saúde (Gesundheitsreformgesetz - GRG) de 1988

Direito sanitário

Regras de inclusão

Rcorganização do direito sanitário no Livro V do Código Social;

Liberação de opcrários de altos salários da obrigatoriedade de filiação ao GKV e restrições para o asseguramento de aposentados e autônomos;

Restrições no catálogo

Novas açōes

Mecanismos de regulação

Aumento de valores e alterações no co-pagamento;

Aumento da participação financcira dos segurados - próteses dentárias;

Introduçăo co-pagamento para 'outros métodos terapêuticos';

Cuidados de longa duraçăo em caso de dependência severa;

Medidas de promoção da saúde, medidas específicas de prevençāo individual e profiláticas para a saúde bucal;
Unificação do catálogo com restrição da oferta de açōes adicionais; Ampliação da competência das Caixas sobre a formação de preços dos medicamentos com a criação de sistema de preços máximos para a assistência farmacêutica (a serem pagos pelas Caixas às farmácias) e para meios de ajuda (próteses, lentes, aparelhos de audiçâo) (Festbetrag);

Reforço da competência das Caixas no controle dos serviços prestados: possibilidade de descredenciamento de hospitais; novas provas de controle de eficiência;

Ampliaçāo da competência das Comissões Conjuntas de Caixas e Médicos na definição de normas de qualidade;

Obrigação legal de negociação de tetos máximos para o setor ambulatorial. 


\section{Quadro 7 - Principais medidas da Lei da Estrutura da Saúde (Gesundheitsstrukturgesetz - GSG) de 1992}

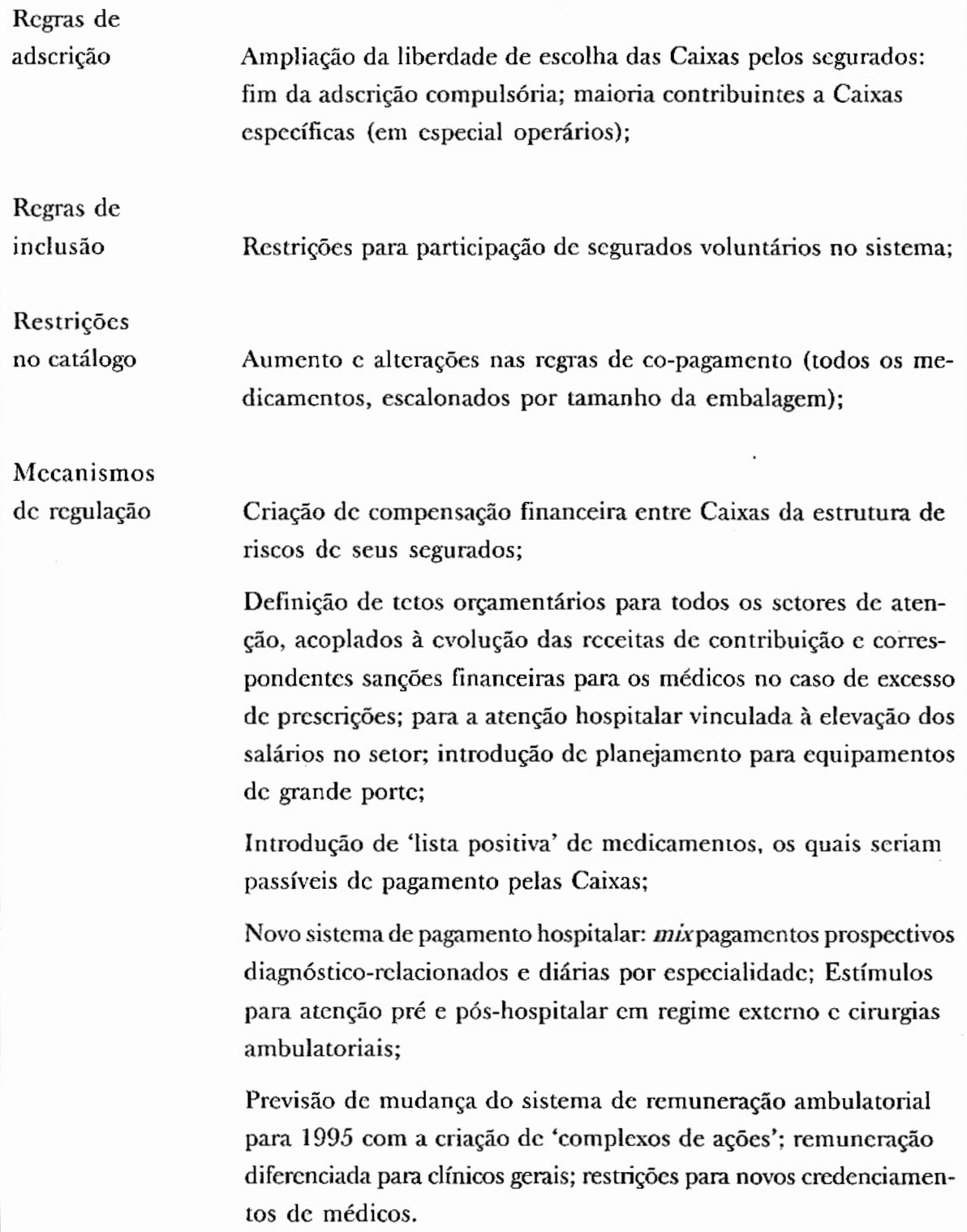

Previsão de mudança do sistema de remuneração ambulatorial para 1995 com a criação de 'complexos de açōes'; remuneração diferenciada para clínicos gerais; restriçōes para novos credenciamentos de médicos.

A lógica geral do mecanismo é que as Caixas com estrutura de risco mais vantajosa do que a média, de acordo com as características correspondentes aos critérios incluídos na compensação, transfiram parte de suas receitas para aquelas 
com estrutura de risco pior que a média. $\mathrm{O}$ cálculo para definição do volume de transferências financeiras é complexo e pondera a pressão diferente destes fatores em gastos e receitas de cada Caixa. São definidos perfis de gastos padrão por grupos de segurados, diferenciados por idade e sexo a partir de médias nacionais. Esses perfis mostram a dessemelhança de gastos médios segundo idade e sexo. Com esta base, estima-se para cada Caixa o que seria a sua 'necessidade de receitas', dada a composiçāo de seu grupo de segurados, ou seja, calcula-se um gasto padronizado por Caixa segundo o perfil de seus segurados.

Esse gasto padronizado é comparado com a 'capacidade financeira' da Caixa. A capacidade financeira de uma Caixa, por sua vez, é aferida a partir da renda de contribuição de seus segurados, multiplicada por 'taxa única de necessidade de compensação'. Esta resulta da divisão da necessidade total de receitas do GKV, ḑada a composição total dos segurados, pelas receitas de contribuição do conjunto das Caixas.

Comparando-se a 'necessidade de receitas' com a 'capacidade financeira' de uma Caixa, define-se sua participação na compensação financeira (Schneider, 1994). Se a 'capacidade financeira' for maior que a 'necessidade de receitas', a Caixa contribui com esta diferença para o fundo de compensação e, em caso contrário, recebe transferências correspondentes à diferença.

A compensação financeira da estrutura de riscos é realizada e administrada pelo Departamento Federal de Seguros, órgão que cobra e distribui os recursos financeiros entre as Associações de Caixas, as quais se encarregam de repartir os recursos para suas associadas.

Anteriormente, vigia apenas compensação da participação diferenciada dos aposentados entre as Caixas. Da mesma forma que as taxas de contribuição dos segurados eram médias nacionais, as despesas com saúde dos aposentados eram divididas, e essas transferências financeiras cobriam os gastos reais produzidos pelos aposentados de cada Caixa. Os gastos com aposentados eram computados em nível nacional, depois de calculadas as médias nacionais e compensadas as diferenças. ${ }^{262}$

As transferências financeiras referentes à compensação de riscos não compensam os gastos reais de uma Caixa, apenas o fazem parcialmente, segundo os critérios acima enunciados. Esses critérios estão relacionados aos riscos e não às despesas, o que estimularia a busca por maior eficiência. Se as despesas reais de seus segurados forem mais baixas do que a média padrão utilizada na compensaçāo, a Caixa receberá/permanecerá com os valores desta diferença. Se forem mais altas, a Caixa terá de arcar com elas, o que resulta na majoração da taxa de contri-

262 Estima-se que algumas Caixas teriam taxas extremamente altas se não houvesse um sistema de compensação. As Caixas de Mineiros, por exemplo, teriam taxas de $21 \%$ e as Caixas Locais de algumas regiões poderiam atingir taxas de 19\% (Dudey e Reschke, 1997). 
buição, conseqüentemente tornando a Caixa menos atraente aos segurados. Assim, para permanecer em boa posição na competição, seria necessário que houvesse controle de gastos.

A compensação financeira da estrutura de riscos é importante instrumento de aproximaçāo das taxas de contribuiçāo, aumentando o potencial de redistribuição solidária ao interior do sistema. Este mecanismo busca desestimular a seleção pelas Caixas dos bons riscos e/ou a discriminaçāo de grupos mais propensos a adoecer ou de menor renda. Entretanto, ao desconsiderar a morbidade, não impede completamente a seleção de riscos.

Além dos fatores incluídos na compensação financeira, analisados anteriormente, está em curso a discussão quanto à consideração de outros critérios no mecanismo de compensação de riscos. Como um dos principais problemas deste mecanismo no sentido de falhar na compensação de riscos, indica-se a não consideraçāo direta da morbidade com a inclusão de critério correspondente, como, por exemplo, a proporção de doentes crônicos. Inquéritos populacionais têm demonstrado importantes diferenças de morbidade entre os diversos tipos de Caixas (Wysong \& Abel, 1990). Para melhorar a compensação, sugere-se que sejam incluídos na compensação critérios tais como proporção de deficientes, internações hospitalares, entre outros (Wysong \& Abel, 1996). ${ }^{263}$ Teme-se que, em situação de intensificação da competição entre as Caixas, a distribuição desigual do peso de outros fatores de risco entre as mesmas possa levar à conformação de mecanismos de seleção de certos grupos conforme a morbidade.

O nível de compensação de riscos alcançado pelo mecanismo de compensação implementado é também motivo de disputa. Se, por um lado, Caixas que pagam ao fundo de compensação, reclamam que a compensação desestimularia a competição ou que os critérios estariam superdimensionando riscos e produzindo transferências excessivas, por outro, autores alertam para o perigo da continuidade de seleção de bons riscos devido a insuficiências na compensação. Estima-se que uma compensaçāo de riscos com base apenas em critérios sociodemográficos como a alemã pode cobrir apenas de $10 \%$ a $25 \%$ da variação dos gastos diferenciados com utilização. Desse modo, é de pressupor que ocorrerá compensação deficiente das Caixas com maior número de segurados de riscos mais elevados.

Afora isso, a compensaçāo financeira da estrutura de riscos foi implementada separadamente entre as regiões oriental e ocidental. As Caixas da Regiāo Oriental defrontam-se com dificuldades crescentes. Suas despesas são si-

2633 Não há, porém, consenso na literatura quanto a tais fatores. São também apontados como apresentando maior risco - desempregados, trabalhadores de tempo parcial, inválidos, beneficiários da assistência social, aposentados por invalidez - e outros, ainda, são tidos como risco grave - hemofílicos, pacientes de diálise e infectados com HIV. Outro aspecto reclamado é a proporçāo de segurados dispensados do co-pagamento por sua baixa renda (Härtefälle). $\mathrm{O}$ argumento é que geraria impacto negativo nas receitas de co-pagamento. 
milares àquelas das Caixas da Região Ocidental, mas sua base de financiamento é mais estreita - por causa da defasagem do nível de renda de seus contribuintes - e em conseqüência suas taxas de contribuição são mais elevadas. Para amenizar o problema, em 1999, foi programado um aumento de 0,1 ponto percentual nas contribuiçōes de todas as Caixas da região ocidental para subvencionar as Caixas da região leste (BMG, 1998a). Posteriormente, a coalizão social-democrata/verde unificou a compensação financeira em nível nacional. ${ }^{264}$

Contudo, comparativamente à situação anterior a 1993, a 'compensação financeira da estrutura de riscos' tornou a seleção de riscos mais difícil. Incluiu critérios que são transparentes quando da inscrição de segurado a uma Caixa: idade, sexo, renda e número de filhos. Não seria proveitoso para uma Caixa, com base em algum desses critérios, sugerir ao pretendente a contribuinte que procurasse a concorrência ou mesmo negar a sua inscrição por meio de subterfúgios, pois essas características são compensadas (Dudey \& Reschke, 1997). Resultados da compensação financeira da estrutura de riscos entre as Caixas já se fazem notar em termos de aproximação das taxas de contribuição. ${ }^{265}$

Observa-se gradual redução das diferenças entre taxas médias de contribuição dos diversos tipos de Caixas. $\mathrm{O}$ intervalo correspondente à variação entre a maior e a menor taxa média de contribuição diminuiu de 2,36 para 1,16 pontos percentuais entre 1992 e 1997 e as taxas médias de contribuição de Caixas Locais e Substitutas para Empregados tornaram-se similares. Permanecem, porém, expressivas diferenças entre Caixas individuais.

Em síntese, a compensaçăo da estrutura de riscos teve por objetivo permitir a implementação de nova ordem competitiva ao interior do GKV e simultaneamente proteger o princípio da solidariedade. Representa, ao mesmo tempo, ampliação da solidariedade ao promover maior redistribuição entre as Caixas em cada regiāo.

A grande coalizão que permitiu o acordo e a definição desses importantes mecanismos, contudo, teve caráter provisório. A política de clientela tornou-se evidente durante a implementação da Lei da Estrutura da Saúde. A elaboração de lista positiva, definida na GSG, não foi adiante por pressão da indústria farmacếutica. A proposição de lista alternativa pela Câmara Médica de Berlim resultou em processo instaurado por iniciativa da indústria farmacêutica. As possíveis economias para o sistema produzidas por sua introdução significariam perdas para a indústria farmacêutica e, por isso, esse potencial de otimização do sistema não foi

264 A Lei para Adaptação do Direito no GKV, unificando a compensação financeira da estrutura de riscos das regióes ocidental e oriental foi aprovada no Conselho Federal (Bundestat) em 17 de dezembro de 1999, com o apoio dos governos democrata-cristãos da regiăo oriental (Deppe, 2000).

265 Os resultados da liberdade de escolha das Caixas em termos de movimento de contribuintes ainda não podem ser avaliados, pois a troca de Caixa pelo segurado antigo tornou-se possível apenas a partir de 1997. 
utilizado. No caso dos médicos, o governo aumentou posteriormente o orçamento do setor ambulatorial, contemplando os médicos com mais 500 milhões de dólares. As sanções que os médicos sofreriam com a redução de suas rendas caso ultrapassassem o orçamento de medicamentos por meio das prescrições foram empregadas apenas parcialmente.

Os efeitos de contenção da Lei da Estrutura da Saúde (GSG) fizeram-se sentir imediatamente. Após déficit recorde, em 1992, o GKV fechou o ano de 1993 com superávit de 10,4 bilhōes de marcos; dentre os quais, 2,5 bilhões provenientes do desembolso direto dos segurados por conta dos aumentos do co-pagamento (Quadro 5).

\section{Terceira Etapa da Reforma do Seguro Social de Doença Alemão (Dritte Reformstufe)}

A discussão a respeito de uma 'terceira etapa da reforma do seguro social de doença' foi iniciada imediatamente depois da entrada em vigor da Lei da Estrutura da Saúde (Gesundheitsstrukturgesetz), em janeiro de 1993, e desenrolou-se, por longo período, até junho de 1997, quando a coalizão governamental teve aprovadas as propostas após diversas iniciativas.

Em 'rodada preliminar', de 1993 a meados de 1996, os diversos atores sociais e partidos posicionaram-se e apresentaram suas sugestōes. O Conselho de Experts para a Ação Concertada em Saúde expôs recomendações para reforma com perspectiva de longo prazo por solicitação do Ministério da Saúde. Os partidos encaminharam propostas ao parlamento: a coalizão conservadora-liberal e o partido social-democrata elaboraram projetos de lei e o partido verde apresentou moção. Os principais atores sociais posicionaram-se a respeito desse conjunto de proposições lançando documentos específicos.

Os projetos de lei da coalizão democrata-cristã/liberal referentes à terceira etapa da reforma da saúde foram enviados ao parlamento ao final de 1995 e início de 1996. O cerne da primeira proposta governamental foi apresentado no projeto Lei para o Desenvolvimento da Reforma Estrutural do GKV (Gesetz zur Weiterentwicklung der Strukturreform in der gesetzlichen Krankenversicherung) (CDU/CSU/FDP, 1996b). ${ }^{266}$

266 Outro projeto, tido como parte da terceira etapa, a Lei de Reordenação da Atenção Hospitalar (KrankenhausneuordnunGSGesetz) (CDU/CSU/FDP, 1995c), visava a implementar mudanças importantes no financiamento hospitalar, tal como a definição de tetos para o setor em nível estadual, acordados entre as associações de caixas e associação estadual de hospitais. 
O propósito principal da coalizão governamental com a terceira etapa da reforma do Seguro Social de Doença era estabilizar as taxas de contribuiçāo. Para tal sugeriu a promoção de maior 'competição' no âmbito do sisterna e o aumento da 'responsabilidade própria' de todos os participantes. As potencialidades da administração autônoma em termos de garantia da economicidade do sistema deveriam ser exploradas a fim de colocar um ponto final na necessidade de contínua intervenção dos legisladores. Para isso, seria preciso ampliar a autonomia administrativa nas áreas de serviços e contratos e tornar mais transparentes os custos dos serviços, aumentando a responsabilidade financeira dos participantes da administração autônoma (CDU/CSU/FDP, 1995a; CDU/CSU/FDP, 1996b).

O partido social-democrata (SPD) apresentou um projeto de lei próprio no Parlamento também em 1996. Por sua intensa participaçāo na elaboraçāo da lei de 1992, Lei da Estrutura de Saúde (GSG), na qual a maioria de suas propostas foi incluída, o SPD considerava ser a crise financeira decorrente da falta de empenho do Executivo na adoção das devidas providências para a implementação desta lei. Alguns artigos foram revistos e outros abolidos, como foi o caso da lista positiva de medicamentos, e outros parcialmente implementados. Para o SPD, os principais problemas do sistema teriam sido enfrentados com a lei anterior. Propôs, assim, uma lei com o objetivo de consolidar as soluções propostas pela lei anterior à Lei de Consolidação da Estrutura de Saúde (GSG II) (SPD, 1996).

Essa rodada de discussões, entretanto, não levou à produção de novo consenso. A coalizão conservadora-liberal teve seus projetos de lei reprovados pelo Conselho Federal (Bundesrat), iniciando ofensiva restritiva mais intensa em 1996.

Os primeiros projetos de lei da coalizão governamental estiveram na discussão até o segundo semestre de 1996, quando foram recusados pelo Conselho Federal (Bundesrat). ${ }^{267}$ As possibilidades de aprovaçāo desta proposta governamental para a 'terceira etapa da reforma do GKV' em seu conjunto foram avaliadas, mesmo pela imprensa conservadora, como baixas, em virtude tanto de seu conteúdo polêmico como da forma do processo legislativo alemāo. Leis que afetam competências estaduais, após aprovadas no Parlamento Federal (Bundestag), devem Ter a concordância do Conselho Federal (Bundesrat). ${ }^{26 \dot{8}}$

267 Deste primeiro conjunto de projetos de lei, apenas um - relativo à assistência larmacêutica foi aprovado. Por pressão da indústria farmacêutica, os medicamentos com proteção de patente foram excluídos, em janeiro de 1996, do sistema de preços máximos acordados pagos pelas Caixas (Festbetrag). A indústria farmacêutica exigiu esta alteração como compensação para investimentos em pesquisa (FR., 27.08.96).

268 O Conselho Federal (Bundesrat) tem sua história ligada ao processo de constituição do Estado alemāo. Com a formação do império alemăo (Deutsche Reich), por Bismark, em 1871, os estados compoenentes mantiveram certa autonomia, garantida por um conselbo de representantes. Após a segunda guerra mundial, com a criação da República Federal Alemã, em 1949, na regiăo da Alemanha ocupada por americanos, franceses e ingleses, a autonomia dos estados, em particular nas áreas de cultura e educação, foi garantida pela constituição do

(continua) 
No processo formal de votaçāo, um projeto de lei passa por três leituras ordinárias no Parlamento Federal (Bundestag), indo então para o Conselho Federal (Bundesrat), composto por representantes diretos dos governos estaduais, em geral, os próprios governadores. Em caso de conflito no Bundesrat, aciona-se uma Comissão de Conciliação entre as duas Câmaras na tentativa de negociar acordo. Se houver acordo nessa comissão, o projeto volta ao Parlamento, onde é aprovado.

Para temas de competência exclusiva da União, a concordância do Bundesrat não se faz necessária. ${ }^{269}$ Nesse caso, uma lei pode ser aprovada no Bundestag por maioria absoluta - $50 \%$ mais um dos votos do conjunto dos parlamentares -, maioria que garante a escolha do chanceler (Kanzler).

Para esses primeiros projetos de lei governamentais da terceira etapa, era necessária a concordância do Conselho Federal. Como a coalizāo governamental não detinha a maioria nesta Câmara, a aprovaçāo dos mesmos era dependente de acordo com social-democratas - governantes da maioria dos estados - e verdes coligados aos social-democratas em alguns estados. Os social-democratas recusavam-se a negociar, caso não fossem implementadas primeiro as decisões anteriores assumidas na 'segunda etapa da reforma', especialmente a elaboração da lista positiva para medicamentos e as sanções dos prestadores estipuladas pela lei. Não se tendo chegado a acordo entre representantes da oposição e governo, os projetos de lei foram recusados.

A coalizão governamental considerou, como primeira lei a integrar a 'terceira etapa', a Lei de Alívio das Contribuições, de caráter unicamente contencionista, componente de um pacote econômico, o Sparpaket sancionado em setembro de 1996. As leis da 'terceira etapa' propriamente ditas, as Leis de Reordenação do Seguro Social de doença (1. und 2. GKV-NeuordnunGSGesetz) foram apresentadas pela coalizão governamental ao final de 1996 e aprovadas em julho de 1997 quase na íntegra, com poucas reformulaçōes.

\section{Rodada preliminar: propostas dos principais atores sociais}

Em janeiro de 1993, o Ministro da Saúde solicitou um parecer especial acerca da futura evolução do Seguro Social de Doença (GKV) ao Conselho de

Conselho Federal (Bundesrat). Na área da saúde, a concordância deste conselho é obrigatória no que diz respeito à formação de profissionais da área e à atenção hospitalar. O Conselho Federal (Bundesrat) é composto por representaçôes dos governos estaduais; em geral, os próprios governadores tomam parte nas reuniōes.

269. Porém, se uma lei for recusada no Bundesrat por $2 / 3$ dos seus integrantes, para ser aprovada no Bundestag, deverá também Ter aprovação igual ou superior a 2/3 (Am Orde, 1997). 
Experts da Ação Concertada em Saúde (SVR), ${ }^{270}$ como contribuição à 'terceira etapa da reforma da saúde', a qual deveria apresentar perspectiva de longo alcance, com o intuito de evitar a contínua intervençāo do 'legislador' (SVR, 1994).

Sob a égide dos princípios básicos da solidariedade e subsidiariedade, o conselho foi encarregado de analisar o impacto da evolução demográfica, das previsíveis mudanças na morbidade e do progresso médico tecnológico na utilização e oferta de serviços médico-sanitários. A principal tarefa consistiu em avaliar a necessidade de modificar ou diferenciar futuramente o catálogo de açōes médico-sanitárias do GKV. O Conselho deveria ponderar se determinadas ações seriam excluídas do catálogo e se novas açōes deveriam ser incluídas; se certos riscos ou ações poderiam vir a ser contratados livremente; e, no futuro, se deveriam ser introduzidos limites e definidas prioridades ao interior do catálogo de açōes médico-sanitárias do Seguro Social de Doença. Além disso, deveria propor formas para a introdução no sistema de fortes estímulos para prevenção ligada às causas $\mathrm{e}$ à assunção de estilos de vida saudáveis (SVR, 1994).

O Conselho de Experts, a partir da atribuição ministerial, elaborou o relatório intitulado 'Proteção à Saúde e Seguro-doença 2000: responsabilidade própria, subsidiariedade e solidariedade frente a um contexto em mudança' (SVR, 1994) como contribuição ao debate entre os diversos atores sociais. Esse relatório continha a maioria das análises solicitadas e desencadeou o debate coletivo acerca da terceira etapa, cuja discussão acirrou os ânimos. Foi criticado especialmente por apresentar diferentes sugestōes para limitação da cesta de ações e benefícios garantidos, sendo considerado por sindicalistas como a defesa da divisão da atenção em medicina de primeira e segunda categorias (EngelenKefer, 1995). Em 1995, o SVR expôs suas recomendações em novo relatório no qual o peso das restrições ao catálogo foi relativizado por conta da polêmica produzida (SVR, 1995).

As principais recomendações referiam-se: ao estabelecimento de maior competição entre as Caixas por meio da ampliação de alternativas, as quais pudessem ser ofertadas por Caixas e prestadores aos segurados; à exclusão do catálogo das açōes tidas como estranhas a um seguro de saúde; à constituição de cestas de serviços adicionais para escolha pelos segurados, tendo taxas de contribuição diferenciadas como contrapartida e à oferta de taxas distintas de co-pagamento. Sugeria ainda a definição de taxa única de contribuição dos empresários - correspondente à metade da média das taxas de contribuição para o Seguro Social de Doença - e apresentava modelos teóricos alternativos para mudança do atual sistema de

270 Em 1992 foi criado o Conselho de Experts para a Açāo Concertada em Saúde, que elabora avaliações anuais a respeito do setor saúde. O Conselho é composto por sete membros 'independentes' de notório saber na área da saúde ou economia, escolhidos pelo Ministro da Saúde com a participação dos membros da Ação Concertada (SVR, 1994:232). 
seguro social: seguro familiar financiado por contribuigōes proporcionais à renda familiar total, seguro privado obrigatório e sistema nacional de saúcle financiado por recursos fiscais, sem indicar, contudo, quaisquer destes.

Parte dessas recomendaçōes do SVR quanto à diversificagão do catálogo e de oferecinento de opsões para o contrato com os segurados foram incorporadas às propostas governamentais posteriomente formuladas e integraram a I ci de Reordenação da Saúde (2.NOG).

Em meados de 1995, o ministro da Saúde, Sechofer; convidou os integrantes da As̆ão Concertada em Saúde a discutirem a terceira etapa da reforma da saúde. Um scminário foi promovido pelo Ministério em Pertersberer criando-se a expectativa entre de que a nova ctapa da reforma seria amplamente debatida e: negociada. Aparentemente, o Ministro partilhava do consenso existente (nntre os principais atores sociais de (jue seria necessário chegar a acordo em que os diferentes interesses e direitos fossem levados em conta (Am ()rde, 19997).

A maioria das organizagōes representatioas dos diversos interesses na área da saúde lanģou documentos nos quais se posicionava quanto ao (que julgava ser problemas do setor, da mesma forma que aprescontava sugestós para seu equacionamento a longo prazo. Todas as Associaçoes de Caixas, organizaçoes dos prestadores de servişos, Câmara Médica, associaģões médicas, dentistas, indústria farmacêutica, trabalhadores, cmpresários, scguros privados, cutre outros, formularam explicitamente propostas para a terceira ctapa (Stegmüller, 1996) (2a). ${ }^{271}$

A scguir, são sumariadas as posiçōes dos principais atores sociais - Caixas, cmpregadores, trabalhadores e médicos -, com a finalidade de analisá-las, juntamente com as propostas partidárias, quanto ao seu alinhamento e concepsōes gerais para a reforma.

São sintetizadas as propostas dos principais atores sociais gerais atuantes no setor - Federação dos Sindicatos Alemäes (DGB - I) (utscher (jeverkischaltshlund), principal central sindical alemã e Federação Nacional das Associações de Empregadores Alemães (BDA - Bundesvercinigung der Deutschen Arbcitgeberverbände), que reúne a maior parte dos empresários alemães - e dos principais atores mais especificamente setoriais: as Associações das Caixas de Doença c a Federação Nacional de Médicos das Caixas ( KBV - Kasscnärztliche Bundesrcroingung).

$\hat{E}$ interessante obscrvar que os principais atores sociais vinculados à produção atuam no âmbito da formação da política de saúde. Esta é uma expressão setorial da forma específica de relação Estado/sociedade neocorporativa e do modelo de seguro social no qual são delegadas pelo Estado funçóes públicas a organizações administradas por trabalhadores e cmpresários.

271 Para uma descricão das propostas e detalhamento dos projetos de lei, consulte Giovanella, 1998 - Rodada preliminar: propostas para a terceira etapa c posiçoes dos principais atores sociais. 


\section{Competição solidária: proposta das Caixas}

Em 1994, as Caixas apresentaram uma proposição conjunta para a terceira etapa da reforma da saúde, não obstante divergirem em diversos aspectos e apresentarem interesses conflituosos: entre si, devido à competição entre as mesmas $\mathrm{e}$ às clientelas distintas, e ao seu interior, em virtude da composiçāo paritária dos órgãos de administração. Em documento de consenso elaborado por um grupo de trabalho constituído pelas oito Associaçōes Federais das Caixas (Spitzverbände der Krankenkassen), denominado 'Ordem competitiva solidária para um seguro social de doença voltado para o futuro'. Fizeram análise dos desafios futuros do GKV e apresentaram sua concepção da competição para o sistema, assim como medidas específicas para o controle de gastos e melhoria nos diversos setores da atençāo (AG-KK, 1994).

As Caixas consideraram, como propósitos de uma reforma do GKV, a necessidade de reorientação de sua atuaçāo no sentido de pautá-la pelo alcance de resultados em saúde e a concomitante garantia futura da atenção de qualidade prestada de modo eficiente e adequada às necessidades de saúde dos segurados. $\mathrm{O}$ princípio da solidariedade não poderia ser colocado à disposição. Futuramente, cada segurado, em caso de doença, deveria continuar tendo acesso à atenção médica de alta qualidade, independente de sua capacidade de financiamento.

No documento, as Caixas afirmaram ser necessário o emprego mais eficiente dos recursos sem atingir o princípio da solidariedade, tendo em vista os desafios decorrentes: da continuidade às tendências hoje evidenciadas de aumento das doenças crônico-degenerativas e da multimorbidade, da mudança do paradigma na atenção médica no sentido de proporcionar abordagem integral às pessoas e ainda os relacionados à evolução da economia e do mercado de trabalho.

O instrumento decisivo para aumentar a eficiência do sistema na visão das Caixas seria o desenvolvimento dos mecanismos competitivos introduzidos pela Lei da Estrutura da Saúde (GSG). Essa competição, contudo, foi adjetivada. Uma atenção de melhor qualidade, adequada às necessidades e, ao mesmo tempo, eficiente, prestada de modo a esgotar todas as reservas de economicidade e as potencialidades de racionalização do sistema, seria garantida mediante uma 'competição solidária' (AG-KK, 1994).

Para as Caixas, os problemas de condução e de financiamento da atenção à saúde estariam relacionados à dominância dos prestadores. As causas para a evolução expansiva dos custos e para os déficits da assistência estariam na assimetria de poder entre prestadores e provedores de seguros, ${ }^{272}$ pendendo para o lado da

272 Utilizarei a denominação provedores para os financiadores; em alemão seria Versicherungsträger, em inglês seria payers. 
oferta de serviços, e na insuficiência da possibilidade de interferência das Caixas em preço, qualidade e quantidade das açōes prestadas, assim como em inadequados estímulos econômicos para os prestadores. Propôs-se, desse modo, o estabelecimento de novas relações entre Caixas e prestadores por meio de política de contratos competitiva, que ampliasse as possibilidades legais de conformação de contratos por parte das Caixas, quanto às condições, estrutura e formas da prestação das açōes de saúde (AG-KK, 1994; AG-KK, 1995 apud Stegmüller, 1996a).

As Caixas teriam assim maiores possibilidades de formular estratégias para a política de contrataçāo, escolhendo adequadas estruturas de atenção e formas de remuneração. Para o funcionamento adequado desta 'ordem competitiva solidária' seria preciso aumentar a capacidade de negociação dos contratantes. Parcerias equilibradas deveriam ser formadas, evitando-se tanto o monopólio como a atomização do mercado. Em especial, seria indispensável redefinir funções para a Associação dos Médicos das Caixas, possibilitando contratos mais flexíveis.

As Caixas propuseram flexibilização das formas de assistência e das formas de prestação de serviços. O objetivo seria revalorizar as atividades de coordenação dos clínicos gerais (Hausarzt) na orientação global em cada caso quanto ao tratamento necessário, corrigindo falhas na atenção e tornando a atenção mais eficiente. Deveriam ser introduzidos estímulos a formas cooperativas na atenção ambulatorial - 'modelo do clínico geral' e 'consultórios em rede' -, assim como entre diferentes áreas da atenção, articulando os setores hospitalar, ambulatorial e de reabilitação e estes com outros profissionais de saúde não médicos, promovendo redes integrativas de atenção.

Em síntese, a concepção de 'competição solidária', conteúdo proposto de forma conjunta pelas Caixas para a terceira etapa da reforma da saúde, teve, como cerne, a política de contratação dos prestadores de serviços. A proposição central foi o estabelecimento de novas formas de organização e a garantia da atenção, em especial no setor ambulatorial, que possibilitassem maior integraçăo e articulação, as quais, por sua vez, poderiam assegurar atenção mais racionalizada e de melhor qualidade.

Para as Caixas, além de o princípio da solidariedade não estar em jogo, os mecanismos de competição deveriam ser introduzidos apenas quando podem promover a eficiência e a qualidade da atenção. Com base em um padrão de asseguramento financiado solidariamente, os pacientes teriam escolha entre estruturas de atenção otimizadas frente a suas necessidades, que seriam colocadas à sua disposição estimulados pela competição das Caixas entre si e pela concorrência entre prestadores. 


\section{Apelo à subsidiariedade e cestas opcionais: a proposta dos empregadores}

A proposiçāo dos empregadores concentrou os argumentos da crítica conservadora-liberal à garantia do bem-estar social. ${ }^{273} \mathrm{~A}$ crise teria como base a "excessiva pressão das contribuições sociais e dos impostos que não seriam mais economicamente suportáveis e tensionariam em excesso o princípio de solidariedade" (BDA, 1994:3). "Um sistema social amplo demais mutilaria o desenvolvimento econômico e corroeria suas bases financeiras" (BDA, 1994:7). Toda a argumentação dos empresários partiu da necessidade de fortalecer a posição do capital alemão na competição internacional, que teria uma das principais desvantagens comparativas nos custos do trabalho. A participaçāo da renda do trabalho na economia, na Alemanha, seria a mais alta do mundo e não chegaria a ser compensada pela alta produtividade do trabalho.

Esses altos custos do trabalho, segundo os empregadores, seriam especialmente determinados pelos custos adicionados, uma vez que a Alemanha ocuparia o quinto lugar na comparação internacional quando considerados apenas os custos diretos, sem adicionais. Esta situação viria a ser agravada pelo progressivo envelhecimento populacional, que traria consigo aumento dos gastos sociais adicionais (BDA, 1996). O objetivo das reformas seria, portanto, aliviar o fator de produção trabalho, reduzindo custos pessoais adicionais e diminuindo, para os empresários, descontos obrigatórios da renda do trabalho. ${ }^{274}$

Os empresários optaram pela continuidade da sua participação no financiamento da proteção social, mas consideraram que a mesma deveria ser delimitada. "Seguro social não é seguro total para todo e qualquer tipo de risco", afirmaram. A cobertura garantida em todos os ramos do seguro social deveria ser revisada e verificada sua correspondência às necessidades atuais. $O$ princípio da subsidiariedade deveria ser reatualizado.

Assim posicionaram-se pela manutenção do financiamento via contribuições sociais. Uma privatização total dos riscos de doença por meio da substituição do seguro social por seguro privado não seria desejável, pois o Estado teria de cobrir benefícios para trabalhadores pior remunerados e aposentados, familiares dependentes etc., o que produziria um $m i x$ público/privado de efeitos duvidosos.

273 A posição dos empresários alemães pode ser apreendida por meio das declarações da Federação Nacional das Associações de Empregadores Alemães (BDA-Bundesvereinigung der Deutschen Arbeitgeberverbände), que divulgou proposição geral de reformulação dos setores sociais, inclusive do seguro social de doença, logo após os resultados da eleição parlamentar de 1994 (Bundesvereinigung der Deutschen Arbeitgeberverbände-BDA, 1994).

$274 \hat{\mathrm{E}}$ interessante observar que uma das formas apontadas pelos empresários para conter custos seria a prcvenção. Medidas preventivas, que evitassem os agravos, seriam mais humanas e menos onerosas, bem como deveriam ser prioritárias, tomando-se, em outras áreas, o exemplo do que é realizado no campo do trabalho. 
Por sua vez, um sistema financiado por recursos fiscais como alternativa às contribuições, mesmo que viesse a significar importante redução dos custos adicionais do trabalho, envolveria maiores encargos fiscais para financiar o novo sistema.

A continuidade de um sistema que se baseia em contribuições estaria condicionada à reatualização do princípio da subsidiariedade, com o objetivo de ampliar a responsabilidade própria dos indivíduos; à delimitação da redistribuição por intermédio da introdução de algum tipo de contribuição complementar para dependentes, o que reforçaria o princípio de equivalência, e ao emprego dos recursos do seguro social para finalidades bem definidas.

Para os empresários, a área da saúde é ramo pujante da economia e as reformas não objetivariam refrear o potencial de crescimento desse setor da economia. A questão seria quais destas ações deveriam continuar a ser financiadas por contribuições obrigatórias pagas em $50 \%$ pelos empregadores. Deste modo, propuseram a introdução de restrições no catálogo de benefícios, optando pela privatização de parte da proteção ao risco de adoecer. Enfatizaram a necessidade de controlar a utilização por meio de mecanismos de controle da demanda que permitissem estabelecer "novo equilibrio entre os princípios de solidariedade e subsidiariedade, tendendo para a subsidiariedade em direção a maior responsabilidade individual" (BDA, 1994:3).

Evidentemente defenderam a competição como elemento essencial da economia de mercado. A competição deveria ser ampliada, possibilitando às Caixas mecanismos para competir relacionados às ações oferecidas e formas de financiamento. Pelo lado dos segurados deveria ser possibilitada a opção entre diferentes cestas. Estes poderiam renunciar a certos benefícios, assim como escolher ações de sua preferência. Benefícios adicionais ao catálogo nuclear seriam pagos somente pelos segurados. Em relação ao financiamento, poderiam ser ofertadas pelas Caixas: a possibilidade de eleição entre diversas formas de co-pagamento, restituiçāo de contribuições e prêmios parcialmente ligados aos riscos.

A ênfase das propostas dos empregadores, portanto, centrou-se claramente em medidas restritivas e que implicavam a privatização pelo menos parcial do risco de adoecer. Não sugeriram medidas que pudessem ampliar a competição entre os prestadores ou racionalizar a oferta, referindo-se apenas à necessidade de ampliação da liberdade de ação dos envolvidos e na introdução de mecanismos de mercado para a condução do sistema.

Defesa da solidariedade e diversificação dos contratos com os prestadores: a posição dos trabalhadores

A DGB (Deutscher Gewerkschaftsbund), principal central sindical alemã, também foi a favor de terceira etapa da reforma da saúde, pois considerava que a 
Lei da Estrutura da Saúde, resultado de amplo acordo, embora tivesse possibilitado melhorias na atenção e enfraquecido a posição dos prestadores, não havia completado a reforma necessária. Uma terceira etapa seria imprescindível para eliminar os déficits de qualidade e as ineficiências ainda existentes, afora possibilitar definitivamente às Caixas e à administraçāo autônoma, em geral, a condução dos gastos setoriais de forma adequada $\mathrm{e}$ independente.

A estabilização das taxas de contribuição seria necessária. Os trabalhadores não poderiam continuar pagando contribuições cada vez mais elevadas sem que recebessem, como contrapartida, um adicional em saúde. As contribuições crescentes teriam resultado principalmente no aumento da renda e faturamento dos prestadores - médicos, dentistas, hospitais etc. - e muito pouco em melhorias da atenção (Engelen-Kefer, 1995:281). ${ }^{275}$ As Caixas deveriam ser munidas de parâmetros que possibilitassem 'competição construtiva' no sentido de mobilizar as reservas de economicidade do sistema e melhorar a qualidade da atenção prestada. Para isto ser alcançado, as estruturas pelo lado da oferta deveriam adequarse (Engelen-Kefer, 1995).

A DGB se posicionou firmemente pela manutenção do sistema de seguro social vigente em suas características e princípios fundamentais. O princípio de solidariedade deveria ser reforçado por meio da ampliação da cobertura do GKV a toda população ocupada, inclusive funcionários públicos, e a elevação do saláriolimite para contribuição ao patamar daquele vigente na previdência e seguro desemprego (DGB, 1994 apud Stegmüller, 1996a).

Tendo por base princípios inquestionáveis de paridade no financiamento, unicidade do catálogo de ações e benefícios, garantia da atenção segundo a necessidade e utilização sem pagamento direto, a DGB considerava ser necessário trabalhar uma concepção global para a reforma que promovesse reorientação da política de saúde, na qual a melhoria dos cuidados fosse valorizada.

Esta reorientação deveria fundar-se em compreensão mais ampliada de saúde, que se aproximasse daquela formulada pela OMS. Aspectos preventivos e psicossociais deveriam ser urgentemente incorporados, abolindo-se a separação existente entre a atenção médica e aquela prestada por outras profissões da área da saúde. Em especial, deveria ser melhorada a atenção a pacientes portadores de doenças crônicas. Na Alemanha, os aspectos fundamentais para o tratamento de doentes crônicos seriam pouco desenvolvidos, como a integração dos setores de atençāo, a continuidade do tratamento e o envolvimento da competência dos pacientes, individualmente e na forma de grupos de auto-ajuda, tornando-os 'sujeitos' de seus cuidados de saúde, em contraposição à condição de 'objeto' forçada pela atual forma de prestação (Engelen-Kefer, 1995).

275 A DGB, como veremos, reivindica especialmente a possibilidade de as Caixas estabelecerem contratos com grupos de médicos e dentistas, o que quebraria os possíveis bloqueios dos prestadores para introdução de mudanças na organização da atenção. 
Uma concepção geral para a reforma deveria ter como objetivos principais: possibilitar a delimitação dos gastos do GKV por meio da definiçāo de orçamento global, acoplado à evolução do PNB; delimitar os âmbitos de competição entre as Caixas, de modo a conduzir a aumento da economicidade do sistema e à melhoria da qualidade da atenção; ${ }^{276}$ promover a articulação entre os setores hospitalar e ambulatorial e formas de atençāo integradas por meio da flexibilização dos contratos, possibilitando melhor coordenação e continuidade do tratamento (Am Orde, 1996; Engelen-Kefer, 1995).

As preocupações essenciais da central sindical foram, portanto, com a superação dos problemas de conduçāo e deficiências de qualidade da atenção e com o esgotamento das reservas de economicidade do sistema mediante a eliminação das ineficiências. Pontos fundamentais da concepção futura do GKV formulada pela Central Sindical (DGB) foram as medidas para maior cooperaçāo entre todas as instituiçôes com responsabilidade na área da saúde. Maior integração entre os diversos setores da atenção, como também a articulação das diversas instituiçōes e órgãos envolvidos na prevenção e promoção da saúde foram propósitos explicitados. ${ }^{277}$

A exigência de introdução de mecanismos de competição no GKV foi avaliada positivamente pela central sindical. Uma concepção de competição solidária e construtiva poderia ser "instrumento para melhoria de qualidade, promoção de inovaçōes e diminuição de gastos, se a mesma for entendida como competição por alternativas de atenção qualitativamente melhores" (DGB, 1994 apud Stegmüller, 1996a:208). O contexto para a competição, entretanto, deveria ser modificado de forma a abrir às Caixas a possibilidade de diversificação dos contratos com prestadores.

Por intermédio da liberdade de estabelecimento de contratos com os prestadores, podcriam ser oferecidas formas alternativas de atenção, respondendo a necessidades dos segurados. Estruturas articuladas para atenção integral dos pacientes, com a participação de outras profissōes da área da saúde, inclusive acompanhamento psicossocial e de cuidados de enfermagem, deveriam ser estimuladas. Os segurados se ligariam por prazos definidos a determinadas redes de atençāo ou centros de saúde que ofereceriam todo o espectro de açōes para prevenção, tratamento e reabilitação. Essas novas formas de organização da atenção contribuiriam para melhorar a qualidade ao evitar ações desnecessárias e reduzir a medicalização e tecnificação dos cuidados com a saúde. Simultaneamente, conduziriam a menor pressão sobre as despesas.

276 Melhorar a qualidade da atenção prestada por meio de instrumentos adequados (inclusive a delinição de protocolos/padrōes para diagnóstico e terapia).

277 A separação entre a atenção ambulatorial e a hospitalar deveria ser abolida, estimulados o atendimento ambulatorial especializado em hospitais e as cirurgias ambulatoriais e organizadas redes. 
Tais formas de organização da atenção propostas pela central sindical (DGB) e pelas Caixas - em boa parte, por influência da DGB, que integra seus órgãos de administração - foram inspiradas em mecanismos de managed care. Para a DGB, administrar os cuidados significa, contudo, a coordenação das responsabilidades médicas, sociomédicas e econômicas, o que não quer dizer que todas estas responsabilidades seriam delegadas aos prestadores. A responsabilidade pela disponibilização de ações de saúde, para garantir atenção adequada, deveria ser compartilhada pelas Caixas e pelos prestadores (Engelen-Kefer, 1995).

Em resumo, a posição da DGB para a terceira etapa não apenas reafirmou o princípio da solidariedade, como pretendeu reforçá-lo. Uma privatização dos riscos, seja sob a forma de racionamento de açōes e exclusōes ou de separação do catálogo em básico c outros de escolha, seja via introdução de contribuições equivalentes aos riscos e bônus por baixa utilização, foi terminantemente rejeitada. Enfatizou medidas preventivas e de promoção da saúde, as quais deveriam ser ampliadas, considerados os aspectos de eficiência no âmbito de um sistema de atenção mais cooperativo e integrado. Déficits de qualidade e de condução, na visão da DGB, deveriam ser sanados por meio da permissão de novas formas de atenção no setor ambulatorial, como as propostas pelas Caixas. Deste modo, seria introduzida uma competição construtiva e solidária e, por isso, aceitável.

A posiçāo da central sindical se sobressaiu dentre as dos outros atores pela manifestação clara e explícita de defesa da solidariedade e da garantia de atenção integral de melhor qualidade; evidenciou, no entanto, algumas contradições. Embora a DGB tenha criticado a centralidade do debate no problema financeiro e denunciado a falta de maior preocupação na solução de deficiências do sistema de atenção, partindo-se de uma concepção de saúde ampliada e a correspondente concepção para atenção integral, a estabilidade das taxas de contribuição apareceu como o primeiro objetivo a ser alcançado em diversos documentos (DGB, 1996a; Engelen-Kefer, 1995; Aḿm Orde, 1996). A DGB, porém, ao contrário das propostas conservadoras, explicitou que, caso fosse comprovada, por dados confiáveis, a impossibilidade de garantia do nível de atenção reconhecido como adequado, a elevação das taxas de contribuição seria justa $\mathrm{e}$ deveria ser permitida.

Contradições do discurso da DGB foram, pelo menos em parte, determinadas pelos conflitos de interesse de seus diversos sindicatos integrantes. Resultaram do embate entre a necessidade da DGB defender a posição do conjunto dos trabalhadores associados e, ao mesmo tempo, a posição de uma parte dos mesmos, os empregados no setor saúde, cujos interesses são distintos. Racionalizações na atenção poderiam estar de acordo com o interesse dos trabalhadores em geral, mas atingiriam interesses diretos dos empregados do setor, afetando a própria 
garantia de seus postos de trabalho. ${ }^{278}$ Além disso, a própria participação da DGB nos arranjos corporativos de administração dos órgãos do seguro social limitava suas possibilidades de intervenção (Stegmüller, 1996a).

O principal problema das proposições da DGB situa-se na visão de que a competição poderia ser utilizada exclusivamente para melhorar a qualidade da atenção prestada. A competição entre as Caixas faz sentido se estas oferecerem açōes e preços - contribuições - diferenciados, o que é incompatível com o princípio da solidariedade defendido reiteradamente pela central sindical (Stegmüller, 1996a).

\section{Gapantindo seu monopólio na prestação: a posição da Federação das Associações de Médicos das Caixas}

De modo geral, a corporação médica posicionou-se favoravelmente aos projetos de lei apresentados pela coalizão governamental para a terceira etapa da reforma do sistema de Seguro Social de Doença. Concordou com os objetivos afirmados de garantia de medicina de alta qualidade e com a necessidade de, tanto quanto possível, conter custos, mas duvidou que isto pudesse ocorrer sem restrições no catálogo de serviços. Se, apesar de todos os esforços para a racionalização da prestação de serviços, os meios financeiros não fossem suficientes para garantir atenção de qualidade, o Estado deveria assumir a responsabilidade de racionamento das açōes ou abrir a possibilidade para a cobertura de financiamento adicional (BÄK \& KBV, 1996).

A corporação médica posicionou-se a favor da introdução de restrições no catálogo de serviços, mas de forma limitada. Argumentou que, a longo prazo, as mudanças na estrutura da população e o progresso médico colocariam novas exigências financeiras e que se tornaria impossível alcançar a estabilização nas taxas de contribuição sem clara delimitação do que deveria ser financiado solidariamente. Considerou que o catálogo de açōes obrigatórias deveria limitar-se às açōes correspondentes às necessidades médicas, o que significaria a introdução de restrições no atual catálogo, evitando-se que as Caixas em competição viessem a oferecer serviços supérfluos como um mecanismo de marketing na disputa por mais segurados. As açōes tidas como supérfluas foram aquelas prestadas principalmente por outros profissionais que integram a área da saúde: não médicos, como fisioterapeutas, fonoaudiólogos, massagistas etc. ${ }^{279}$

278 O Sindicato dos Trabalhadores nos Setores Público, Transporte e Carga (ÖTV) lançou documento próprio, manifestando-se contrariamente à implementação da regulação da Lei da Estrutura da Saúde e de mecanismos de competição entre prestadores.

279 Para exemplificar, referiram-se ainda à fecundaçāo artificial e à densitometria óssea (Die Welt, 29.05.96). 
Para os médicos, a defesa de maiores restriçōes seria, em certa medida, uma opção pela redução dos serviços que poderiam prestar com remuneração garantida, motivo pelo qual a introdução de medidas que levariam à privatização de riscos foi pouco defendida por eles, embora se alinhassem com as posições conservadora-liberais.

Aprovaram igualmente os estímulos para os segurados assumirem maior responsabilidade na utilização de serviços, o que significa dizer que se mostraram a favor do co-pagamento, embora recusassem sua introdução no setor ambulatorial.

A corporação médica defendeu enfaticamente a manutenção da atual estrutura de poder ao interior da administração autônoma, em especial quanto a sua própria posição. Posicionou-se contrariamente a qualquer procedimento que implicasse em alguma alteração de sua atuação como representante do conjunto dos médicos. Negociações somente deveriam ser realizadas entre as Associaçōes de Médicos das Caixas e as Associações das Caixas de forma conjunta. Posicionou-se terminantemente contra a negociação de contratos para a experimentaçāo de novos modelos de atenção apenas com grupos de médicos e contra o credenciamento de ambulatórios ou hospitais por apenas um tipo de Caixa.

Em síntese, a corporação médica, em razão de orientar-se incondicionalmente por seus próprios interesses, defendeu decididamente o contrato exclusivo de garantia da atenção ambulatorial (Sicherstellungsauftrag), que lhe garante o monopólio na prestação, ao mesmo tempo em que assumiu posição moderada frente às restrições e racionamentos de ações, à participação direta dos usuários nos gastos e à divisão do catálogo do GKV em obrigatórios e opcionais. Assim, a defesa da necessidade de novos mecanismos de competição ao interior do sistema pelos médicos mostrou-se mais como a defesa da competiçāo das Caixas entre si, o que fortaleceria a posição dos médicos frente às mesmas.

\section{Mapa das posições dos atores: concepções para a competição}

Desde a discussão da Lei da Estrutura da Saúde (GSG), independentemente de posições e interesses específicos, a maioria dos atores sociais assumiu a 'competição' como palavra-chave para a reforma (Behrens et al., 1996; Gerlinger \& Stegmüller, 1995b). Embora com diferentes ênfases quanto aos determinantes da crise, todos os atores identificaram deficiências na condução do sistema, condicionadas por falta de adequados estímulos à administraçăo mais parcimoniosa dos recursos disponíveis, seja pelas Caixas, prestadores ou usuários. O estímulo à concorrência ao interior do sistema de proteção seria o mecanismo adequado para garantir funcionamento ótimo em termos de sua economicidade. 
O propósito de estabilização das taxas de contribuição esteve presente em todos os discursos como pressuposto na aprèsentação de propostas, mas as concepções dos diversos atores sociais e dos partidos políticos para a competição a ser introduzida no Seguro Social de Doença (GKV) foram distintas. Diferiram, em particular, no que diz respeito à privatização ou não do risco de adoecer e à maneira e extensăo em que esta se processaria, e em como deveriam ser redesenhadas as relaçōes entre Caixas, segurados e prestadores de serviços. Isto é, quem deveria competir com quem: se, principalmente, as Caixas, umas com as outras, por segurados, ou os prestadores entre si, pela venda de seus serviços.

As posiçōes de atores e partidos podem ser qualificadas conforme a ênfase de suas propostas em medidas de racionalização do comportamento da demanda ou em incentivos à racionalização da oferta, clássica tipificação utilizada por economistas da saúde para qualificar medidas de contenção.

As concepções para a competição no GKV também podem ser qualificadas, grosso modo, de acordo com a ênfase nos objetivos que se propõem: controle da demanda ou da oferta. O alinhamento em uma ou outra posição, de modo geral, parte de análise distinta do problema. O controle centrar-se-á no lado da demanda se o problema da expansão dos gastos for considerado como ocasionado por utilização inadequada. Buscará o controle da oferta se a inadequação for localizada na prestação. Embora essa distinção pareça apenas baseada em critério técnico, tem implicações políticas importantes. As soluções, fundadas nas distintas concepções para a competiçāo desejada, afetaram de forma muito diferenciada não apenas os grupos sociais, como o próprio sistema de proteção.

Gerlinger \& Stegmüller (1995b) analisam as propostas dos principais atores sociais para a terceira etapa da reforma do sistema social de seguro-saúde e identificam duas orientações principais para a competição almejada. Para os defensores da 'privatização da demanda', a nova ordem competitiva proposta expressa a perspectiva de imediata privatização dos riscos em saúde, isto é, um deslocamento de gastos para os segurados. Nessa concepção, a maior concorrência entre os prestadores é questão secundária. Por sua vez, a competição é adjetivada como solidária na concepção de 'concorrência da oferta'. A ampliação dos mecanismos competitivos de condução, em particular, por meio do fortalecimento do poder de demanda das Caixas, levaria ao enfraquecimento da dominância dos prestadores.

Nesta formulação, o perigo de privatização dos riscos e gastos em saúde seria afastado por intermédio da manutenção do financiamento solidário e do catálogo de serviços abrangente e único. Exemplos do primeiro grupo sāo as propostas do Conselho de Experts da Ação Concertada em Saúde (SVR) e da Federação Nacional das Associações de Empresários (BDA). Os documentos das Caixas e da Central Sindical (DGB) representam o segundo grupo. 
As concepções dos partidos quanto à competição a ser introduzida no sistema também são diferenciadas. As propostas apresentadas pela coalizão governamental e pelo partido social-democrata denotam os posicionamentos e podem ser alinhadas a uma dessas concepções da competição, embora nem todas as medidas sugeridas possam ser igualmente enquadradas. A posição dos verdes, por sua vez, é mais abrangente, envolvendo outros aspectos para além da competição.

A proposta da Federação Nacional dos Médicos das Caixas, em virtude de suas particularidades, não poderia ser enquadrada nas duas genéricas concepçōes anteriores, segundo os autores, que a denominam de "competiçāo cortada ao meio" (Gerlinger \& Stegmüller, 1995a:10). A corporação médica defende a competição, mas esta deveria ocorrer apenas entre as Caixas e não entre os prestadores. A posição dos médicos tem grande importância, pois a estrutura corporativa do sistema assegura considerável influência dos mesmos na política de saúde.

\section{Concepção de privatização da demanda}

Para os defensores da 'privatização da demanda', a origem do aumento de preços e gastos estaria no fraco desenvolvimento do mercado, condicionado pela excessiva regulamentação estatal. $\mathrm{Na}$ tradição conservadora-liberal, a falta de mecanismos de preços na conduçāo da oferta e da demanda e a 'exagerada' regulamentação estatal seriam sérios impedimentos para alocação responsável e eficiente dos meios financeiros. Somente a revalorização dos princípios de mercado poderia resolver a situação, aumentando a eficiência e contendo gastos.

O problema principal para os adeptos desta concepção estaria na ausência de auto-responsabilidade financeira dos segurados, o que produziria utilização inflacionária: a expansiva utilização de ações de saúde para além das necessidades. Seria preciso uma nova relaçăo entre subsidiariedade e solidariedade para garantir maior responsabilidade de cada um. $\mathrm{O}$ volume do co-pagamento, até então vigente, seria insuficiente. As quantias a serem pagas seriam muito baixas e restritas a poucas ações (BDA, 1994). Uma participaçāo direta e significativa nos gastos pelos segurados conformaria, segundo esta concepçāo, o instrumento apropriado para aumentar a sensibilidade dos usuários aos custos e promover utilização responsável dos serviços de saúde (SVR, 1994). É por esse aspecto principal que se justifica o emprego do termo privatização da demanda para qualificar tal concepção. ${ }^{280}$

Diversos mecanismos foram propostos para o alcance de novo equilíbrio entre a subsidiariedade e a solidariedade e o acréscimo da auto-responsabilidade dos segurados. Esta seria alcançada tanto pela ampliação do espectro e majoração

280 O termo 'privatização da demanda' refere-se especificamente à extensāo do financiamento privado (Granaglia, apud Almeida, 1995). 
do co-pagamento, como também pela separação do atual catálogo unitário de serviços em básico e adicional, de livre escolha pelos segurados, em contrapartida à taxa de contribuição adicional.

O catálogo de serviços vigente seria extenso e contemplaria açōes desnecessárias, com caráter essencialmente de bens de consumo, o que estimularia utilização para além das necessidades. Em vista disso, o Conselho de Experts da Ação Concertada em Saúde propôs a reduçāo do catálogo obrigatório de serviços e sugeriu a constituição de diferentes cestas básicas e catálogos complementares eletivos (SVR, 1994).

A diferença entre estas propostas e as medidas de contenção de custos até então implementadas é que tais formas de privatização do risco de adoecer deveriam ser processadas por meio de mecanismos de competição análogos aos de mercado: a competição das Caixas entre si por segurados.

O Conselho de Experts para a Ação Concertada em Saúde e a Federação Nacional das Associaçōes de Empresários identificaram também reservas de economicidade no lado dos prestadores. Diferentes formas de contratação, negociação e remuneração seriam os instrumentos para explorar estas reservas de economicidade. A possibilidade do estabelecimento de diferentes cláusulas contratuais pelo lado dos prestadores significaria a negociação de formas alternativas de organização da atenção, tais como cirurgias ambulatoriais, paciente-dia, constituição de ambulatórios em hospitais ou introdução de novas formas de articulação entre a atenção hospitalar e ambulatorial, e diferenciação das formas de remuneração: pagamento prospectivo por caso ou por capitação.

A necessidade de maior competição entre os prestadores, porém, é pouco desenvolvida. Como a evolução dos gastos em saúde é entendida, nesta concepção, como problema induzido pela demanda, a privatização dos riscos de adoecimento por meio de co-pagamento e restriçōes na cesta de serviços seriam as respostas-chave.

A concretização das propostas de aumento da participação financeira dos usuários e de diferenciação da cesta presentes nesta concepção descaracterizaria o GKV na qualidade de sistema de seguro social, pois elimina parte importante do espectro de ações em saúde do financiamento solidário ao privatizar parcialmente a demanda. Apenas para uma parte das ações em saúde o princípio constitutivo do sistema 'solidariedade' permaneceria válido e passaria a viger o princípio de equivalência de riscos, até então estranho ao Seguro Social de Doença.

Para a coalizāo governamental democrata-cristã/liberal, todos os participantes deveriam entrar na ordem competitiva. Os mecanismos de preços deveriam conduzir tanto a demanda, quanto a oferta de ações de saúde. A crença baseia-se no suposto do homo economicus, segundo a qual 'apenas quem está consciente que preços muito altos produzem desvantagens na concorrência, podendo significar até a sua falência, ofertará serviços e ações de preços mais adequados. Ainda, apenas quem percebe que açōes médicas custam algo, as utilizará de forma econômica'. 
Na prática, no entanto, a política da coalizão conservadora-liberal ${ }^{281}$ restringiu a competição às Caixas e repassou custos da atenção aos pacientes. Embora a competição devesse incluir todos os participantes do sistema, nas propostas da coalizăo governamental, a concorrência entre os prestadores foi pouco estimulada. A posição de dominância das Associações de Médicos das Caixas permaneceu inalterada. Novas formas de organização da atençāo ficaram restritas a projetos delimitados. O problema principal para a coalizão governamental seria a falta de responsabilidade financeira dos segurados, que produziria utilização inflacionária, ou seja, a evolução dos gastos em saúde é entendida como problema induzido pela demanda. Assim, a privatização dos riscos de adoecimento por meio de copagamento e restrições na cesta de serviços seriam respostas-chave. A concorrência seria a mola mestra para administração mais eficiente das Caixas e para utilização parcimoniosa por parte dos segurados. É esta concepção que ordena as propostas das leis aprovadas em 1997, como veremos adiante.

\section{Concepção de concoprência da oferta}

Na concepção de 'concorrência da oferta' explicitada pelas propostas das Caixas e da Central Sindical (DGB), a evolução expansiva dos custos e as deficiências na qualidade da atenção seriam decorrentes de problemas na oferta, em especial, a assimetria de poder entre prestadores e Caixas - a dominância dos prestadores de serviços -, que implica a baixa possibilidade de intervenção das Caixas quanto à conformação de diferentes alternativas para preços, qualidade $\mathrm{e}$ quantidade dos serviços ofertados concomitante à falta de estímulos para prestação de serviços mais eficiente (Gerlinger \& Stegmüller, 1995a).

Mudanças nas relações entre as Caixas e os prestadores são o ponto central desta concepção. As possibilidades de intervenção das mesmas na defínição das condiçōes, da estrutura e das formas da prestação de serviços deveriam ser ampliadas. A competição entre elas, promovida pela GSG, deveria ter sua correspondência no lado da oferta de serviços.

A modalidade de reforma decorrente dessa concepção implicaria a redefinição do papel das Caixas, que deveria portar-se como compradora de serviços para a sua clientela, enquanto os prestadores concorreriam entre si na oferta de serviços a preços mais favoráveis. Isso seria especialmente necessário no setor ambulatorial para quebrar o monopólio das Associaçōes de Médicos Credenciados.

As Caixas deveriam poder negociar com diversos grupos de médicos diferentes contratos. Nessa situação, os honorários no setor ambulatorial poderiam ser diferenciados e as Caixas teriam maior capacidade de influenciar na qualidade

281 Note-se bem: o conservadorismo da democracia cristã aliado ao neoliberalismo do partido liberal. 
dos serviços prestados. O sistema de honorários médicos deveria ser modificado de modo a deixar de induzir a expansão das ações como a que ocorre com pagamentos por unidades de serviço. Com isso, eliminar-se-ia a atual assimetria de poder entre as instituiçóes públicas provedoras de seguro social e prestadores.

Para as Associações das Caixas, esta nova ordem competitiva não seria contraditória com princípios solidários. A Central Sindical (DGB), embora mais moderada, avalia também positivamente a introdução de maior competitividade. Uma competição solidária e construtiva poderia promover a melhoria de qualidade, a capacidade inovadora e a diminuição de preços.

Nesta abordagem, a competiçāo seria pela forma de atenção mais eficiente e de melhor qualidade. A concorrência entre as Caixas cumpriria a função de procura pela melhor forma de atençāo, constituindo-se em verdadeiras procuradoras dos interesses dos segurados (Gerlinger \& Stegmüller, 1995a). A contratação de formas de atenção mais favoráveis, por sua vez, teria como pressuposto o enfraquecimento da oferta.

Para proteger os segurados contra possíveis efeitos negativos da competição e de privatização dos riscos, o catálogo de serviços deveria ser mantido único, padrôes de qualidade deveriam ser estabelecidos e os espaços de competição limitados. Ainda para a central sindical (DGB), o princípio de solidariedade deveria ser fortalecido por meio da ampliação da cobertura do GKV a toda a população ocupada, inclusive funcionários públicos, e pela elevação do salário limite para contribuiçāo ao nível daquele vigente para a previdência social e seguro desemprego (DGB, 1994 apud Stegmüller, 1996a).

Maior independência para a administração autônoma seria também requisito fundamental à implementação da competição nesta concepção. A introdução da competição implicaria aumento da responsabilidade das Caixas. O Estado permaneceria com as funçōes de regulação e vigilância, mas uma intervenção estatal tão freqüente, como a que ocorria até então, tornar-se-ia desnecessária.

Os social-democratas também posicionaram-se por competiçāo solidária. A competiçāo foi adjetivada de solidária não apenas porque o princípio de solidariedade permaneceria garantido. Como pressupostos para a competição, o princípio de solidariedade teria sido ampliado: a compensação da estrutura de riscos entre Caixas e a ampliação da liberdade de escolha de uma Caixa para a maioria dos segurados tornariam o sistema em seu conjunto mais solidário. Uma solidariedade de grupo restrita ao grupo de segurados de cada Caixa teria sido substituída por solidariedade entre o conjunto de todos os segurados.

Uma das principais medidas propostas dizia respeito à delimitação definitiva dos gastos de saúde. Os gastos por contribuinte somente poderiam crescer em proporção igual à da evolução do PIB. Esta medida foi julgada necessária em decorrência da especificidade da dinâmica de gastos em saúde. Sem delimitação, o setor não seria governável, pois a demanda pode ser fortemente influenciada pela oferta. 
Os prestadores podem estimular a utilização dos serviços e compensar possíveis perdas de remuneração. A definição de tetos orçamentários por tipo de gasto não seria instrumento adequado para delimitar a evolução dos gastos em saúde porque, embora possibilitasse a contenção dos gastos a curto prazo, consolidaria distorções da distribuição de gastos entre os setores, inibindo a criatividade do sistema (SPD, 1996). Já o estabelecimento de limite superior para a evolução dos gastos das Caixas promoveria a almejada estabilizaçāo das taxas de contribuição ao acoplar este limite ao crescimento da economia como um todo. ${ }^{282}$

Para os social-democratas, o problema dos gastos localiza-se principalmente no lado da oferta, devendo portanto ser estabelecida competição entre os prestadores. Defenderam mudanças na organização da oferta e apresentaram, em seu projeto de lei de 1996, uma série de medidas que viria quebrar o monopólio das Associaçôes de Médicos das Caixas na garantia da prestação e promover a competição entre os prestadores, enfraquecendo a dominância dos mesmos nas negociações.

Propuseram, entre outras medidas, a reformulaçảo das associações de médicos e das representações do setor hospitalar, assim como a promoçáo de formas cooperativas de atenção ambulatorial, de contratos integrados entre setores de atenção e a flexibilização da divisão de trabalho entre médicos e hospitais. Demonstraram sua preocupação com a privatização dos riscos e as desvantagens adicionais do co-pagamento para pacientes crônicos, propondo mecanismo para reduzir a participação financeira de doentes crônicos com medicamentos. Embora tenham se manifestado e votado contra as majoraçóes dos valores de co-pagamento, não rejeitam este mecanismo, não tendo proposto sua extinção.

Permanece questão em aberto se a competiçăo entre as Caixas pode ocorrer de forma a que se lhe possa conferir o atributo 'solidária'. Os perigos de seleção de riscos por meio da escolha dos segurados mais atrativos, de estratégias que favoreçam a oferta às custas dos contribuintes e de formas de concorrência que levem à escalada dos preços ${ }^{283}$ foram minorados, mas não abolidos. Com a

282 A vantagem desse acoplamento em relação ao proposto na Lei da Estrutura da Saúde (GSG), que restringiu o aumento dos gastos ao crescimento das receitas de contribuição, é que os gastos em saúde poderão acompanhar o crescimento da economia, mesmo que a participação da renda do traballo não evolua da mesma forma. Isto é, garante-se que os gastos em saúde acompanhem o crescimento econômico do país como um todo.

283 A competiçâo entre as Caixas pelos segurados mais atraentes (jovens, sadios e com melhores salários) pode levar à oferta de melhores preços aos prestadores na expectativa de atendimenı diferenciado. Exemplo anterior a isso ocorreu entre as Caixas para Empregados (Ersatzkassen fiir Angestellte) e as Caixas Locais (Ortskrankenkassen). As primeiras, com estrutura de segurados mais favorável (volume maior de contribuiçōes), negociaram preços mais altos com as associaçōes de médicos contratados, o que despertou maior interesse dos médicos em atender os seus segurados e resultou em atenção mais personalizada, levando as Caixas Locais a fazer o mesmo em seguida, provocando a escalada de preços às custas dos contribuintes. 
competição, mesmo com a implementação da equiparação de riscos, cresce a pressão para desenvolvimento de estratégias de seleção daqueles grupos de pacientes com probabilidade de maiores gastos.

As diferenças de estratégias propostas pelas diversas Caixas quanto ao nível e formas de negociação para o estabelecimento de contratos, bem como as diferenças de concepção quanto à necessidade e forma da equiparação de riscos, são exemplos de divergências que fazem duvidar que a 'competiçāo solidária' entre as Caixas esteja de acordo com os interesses dos segurados (Gerlinger \& Stegmüller 1995a). Em outras palavras, que a competição não venha a ter conseqüências negativas para os segurados.

A posição do partido verde é próxima a esta concepção, todavia, destaca-se. Diferenciou-se das propostas dos outros partidos em razão de sua análise não partir do problema dos gastos. Enfocava aspectos de democratização do seguro social de doença e do sistema de atenção à saúde e problemas de desigualdades na utilização. $O$ partido verde posicionou-se contra a introdução de mecanismos de mercado no sistema, mas concordou, ao mesmo tempo, com a competição entre as Caixas, sugerindo, todavia, a ampliação da compensação financeira da estrutura de riscos e rejeitando veementemente restrições na cesta e seleção de riscos (Bündnis90/Die Grünen, 1996). Os verdes áproximaram-se da posiçāo da central sindical (DGB) no que concernia à necessidade de ampliação da solidariedade, de ênfase na prevenção e mudanças no modelo assistencial. Alinharam-se com as propostas do partido socialdemocrata no que dizia respeito a questões de reorganização da atenção $\mathrm{e}$ ao acoplamento dos gastos do GKV à evolução da economia como um todo.

Desse modo, os verdes assumiram, como princípios: a solidariedade; a atenção igualitária de todas as camadas sociais; a responsabilidade coletiva no que se refere à saúde, em virtude da estreita relação entre condições de vida e de trabalho e saúde; a precedência da prevenção sobre o tratamento; a participação do paciente nas decisões acerca de seu tratamento por meio da promoção da competência individual, alterando a hierarquia na relação médico-paciente, democratizando-a; a atribuição de importância igual para outras profissōes da área da saúde na equipe de saúde; uma visão mais feminina das normas de saúde e tratamento para todos sem discriminação.

\section{Competição partida: médicos e hospitais em defesa de seus interesses}

Os médicos credenciados ocupam posição-chave na prestação e produção de serviços, no sentido de produzir e de provocar a produção, e seriam os principais atingidos com a implementação de maior concorrência pelo lado da oferta, ou seja, entre prestadores. A incumbência dada às associações de médicos credenciados 
de garantia de atenção (Sicherstellungsauftrag), estabelecida no Livro do Código Social, seria colocada em questão. $\mathrm{O}$ monopólio da corporação médica na negociação de contratos do setor ambulatorial seria quebrado. E este certamente não era objetivo almejado pelos médicos. Os médicos, embora tendo mencionado a necessidade de maior competição, fizeram defesa intransigente de seus interesses pela garantia de seu monopólio. Qualquer concorrência entre os médicos quanto a preços foi vista como tendo conseqüências desastrosas. Por sua vez, qualquer definição de normas para os percursos e fluxos de tratamento foi entendida como perda da autonomia profissional.

Pela sua proximidade ideológica com o partido governamental, seu alinhamento com as análises das correntes dominantes a respeito das causas da 'explosão de custos', a Federação das Associações de Médicos das Caixas (KBV) viu-se obrigada a manifestar pelo menos acordo verbal com a introdução de mecanismos de competição setorial. As discrepâncias de sua proposta, porém, foram claras (Gerlinger \& Stegmüller, 1995a). A competição não deveria levar à diminuiçāo da solidariedade entre os médicos, afirmava o documento, rejeitando o estabelecimento de modelo de compra de serviços pelas Caixas.

Negar a competição pelo lado da oferta não significa, porém, negativa completa da competição. O 'modelo de compra' proposto pelas Caixas deveria ser transformado, segundo a expectativa dos médicos, em 'modelo de venda' das Associações de Médicos Credenciados por meio de competição mais acentuada entre Caixas. Em síntese, os médicos defendiam competição restrita pelo lado da demanda. ${ }^{284}$ Eles não podem ser alinhados na concepção de 'privatização da demanda', pois foram contra a introdução do co-pagamento no setor ambulatorial, ainda que não fossem totalmente contra a inclusão de restrições no catálogo e desejassem definir quais. Uma privatização da demanda não seria de seu interesse, pois acarretaria redução de suas rendas, uma vez que parte das açōes nāo teria mais o pagamento garantido pelas Caixas.

A posição da Sociedade Alemã de Hospitais, por ser muito específica e referir-se quase exclusivamente ao setor hospitalar, também não pode ser imediatamente alinhada a essas duas concepções polares. $\mathrm{O}$ documento de tomada de posição da Sociedade Alemã de Hospitais consistiu na defesa explícita de interesses particulares. As principais críticas dos hospitais recaíram no setor ambulatorial. Para conter o crescente déficit, reformas neste setor seriam urgentes. Diversos argumentos foram utilizados para provar essa tese, em especial quanto aos gastos impulsionados pelo crescente credenciamento de médicos no setor ambulatorial e ao alto volume de gastos ambulatoriais per capita na Alemanha.

Por um lado, a Sociedade Alemã de Hospitais insistiu $\mathrm{em}$ maior controle e competição no setor ambulatorial e acatou as mudanças na forma de remuneração

284 Por isso denominada 'competição partida' por Gerlinger \& Stegmüller (1995a). 
hospitalar mediante pagamentos prospectivos, o que a alinharia com a posição de concorrência da oferta. Por outro lado, não se manifestou contra as medidas de privatização parcial da demanda e apoiou as propostas da coalizão governamental em sua primeira versão, o que demonstra defender apenas seus interesses específicos.

\section{Lei de Alívio das Contribuições}

Para além dos déficits específicos do GKV, as novidades da conjuntura mais geral no período final de discussão e aprovação da terceira etapa foram o aprofundamento do desemprego, a proximidade da unificação monetária européia e as dificuldades da Alemanha em cumprir os critérios de Maastricht para garantir sua entrada na união monetária na primeira fase, especialmente o concernente ao déficit de público de, no máximo, $3 \%$ do PNB. Desse modo, uma das principais preocupaçōes governamentais - talvez a principal - passou a ser o controle do déficit público a todo custo, de modo y cumprir o critério que a própria Alemanha formulara em conjunto com os outros países e garantir o sucesso da unificação, iniciativa na qual o chanceler alemão Helmut Kohl fora protagonista. Um afã contencionista tomou conta do governo no momento da aproximação dos prazos para cumprimento dos critérios de Maastricht.

Ainda que os gastos do GKV não sejam gastos públicos diretos, não há como desvincular a intensificação da contenção setorial daquela necessidade de combater o déficit público a toda prova, dada a simultaneidade dos processos, uma vez que os déficits aumentam a pressão para sua cobertura com recursos fiscais.

A urgência de contenção assumida pela coalizão governamental, aliada à opção política de defesa de interesses empresarias gerais, mas também setoriais clientelas governamentais específicas - impossibilitaram negociação mais ampliada para a decisão a respeito da terceira etapa da reforma. Ao final, a opção governamental foi por medidas primariamente restritivas e pela não negociação.

Desse modo, uma lei específica de contenção para o GKV, a Lei de Alívio das Contribuições (Beitragsentlastungsgesetz), constituída por um conjunto de restrições, em sua maioria cortes de benefícios, foi incorporada ao programa de contenção (Sparpaket)-, eufemisticamente denominado Programa por maior crescimento e ocupação, proposto pela coalizão governamental na tentativa de alcançar os critérios de Maastricht para a unificação monetária européia.

Explicitados pela coalizão governamental conservadora no poder, os objetivos do programa seriam: limitar os custos adicionais do trabalho (leia-se custos sociais; fortalecer o princípio de equivalência entre contribuições e benefícios; aumentar a consciência dos segurados quanto aos custos dos serviços de saúde; flexibilizar a legislação trabalhista), o que, supostamente, possibilitaria maior nível de ocupação; fortalecer a dinâmica de crescimento econômico e criar novos 
empregos, garantindo, assim, os fundamentos econômicos do Estado de BemEstar, de forma duradoura (BMAS, 1996a).

Para tal, seria necessário, segundo a coalizăo governamental, que, até o ano 2000, a soma do conjunto das contribuições sociais relacionadas aos salários previdência, saúde, seguro-desemprego, seguro de acidentes de trabalho e seguro para cuidados de longa duração - baixasse para menos de $40 \%$, bem como a participação estatal no PIB, para $45,8 \%$ (patamar pré-unificação). ${ }^{28.5}$

O pacote englobou medidas nas diversas áreas sociais: direitos trabalhistas, previdência social, seguro social de saúde, seguro-desemprego, seguro social e renda-criança (Kindergeld). ${ }^{286}$ Estas, segundo a coalizăo governamental, seriam apenas correçōes necessárias e não atingiriam a estrutura do sistema de seguro social. ${ }^{287}$

A Lei de Alívio das Contribuiçōes definiu uma série de restrições e medidas de contenção de gastos e estabeleceu em $0,4 \%$ a diminuição das taxas de contribuição para janeiro de 1997. Introduziu cortes na utilização de casas de restabelecimento (Kur), assistência odontológica e medidas de promoção; aumentou os valores de co-pagamento para Kure medicamentos; reduziu em 10\% o auxílio-doença sob responsabilidade das Caixas após a sexta semana de afastamento do trabalho e de $20 \%$ no auxílio pago pelo empregador (BundesratDrucksache, 1996; Steffẽn, 1996b; Hüllen \& Schnelle, 1996).

O ponto polêmico - a restriçăo que acirrou mais os ânimos - foi a redução do valor dos salários pagos no caso de afastamento do empregado por doença, benefício a cargo do empregador nas seis primeiras semanas. O valor foi reduzido de $100 \%$ para $80 \%$ do salário anterior. Benefício este conquistado para o conjunto dos trabalhadores assalariados ao final dos anos 60 , às custas de importante mobilização e greves prolongadas. ${ }^{288} \mathrm{~A}$ justificativa para os cortes seria $\mathrm{o}$ abuso de licenças. ${ }^{289}$

Além da redução do valor do auxílio-doença, os principais cortes do catálogo de serviços foram de ações de promoção da saúde e próteses dentárias, abolidas para os segurados nascidos após 1979. Jovens que completassem 18 anos a partir

$28.5 \mathrm{Em} 1995$, o conjunto das contribuiçōes sociais sobre salários era a participação dos gastos governamentais no PIB fora de 50,5\% (BMAS, 1996a:8).

286 Cada criança moradora da Alemanha recebe 200 marcos por mês até completar 18 anos.

287 Para descrição detalhada do 'pacote', consulte Stotz e Giovanella, 1996.

288 Uma das greves mais importantes na história da luta dos trabalhadores pela continuidade do pagamento de salário em caso de doença foi a realizada em 1956-1957 pelos metalúrgicos em Schleswig-Holstein. Após 16 semanas de greve, os trabalhadores conquistaram elevação da complementação do benefício-doença - de responsabilidade das Caixas - paga pelos empregadores, com reposição de $90 \%$ dos salários.

289. Estudos com pacientes que recebem auxílio-doença, entretanto, mostraram que a maioria é de doentes crônicos, sobre os quais pesam financeiramente os cortes, concomitantes aos aumentos de co-pagamento (Braun, Helmert \& Müller, 1997). 
de 1997 não teriam direito à restituiçăo de $50 \%$ dos tratamentos com próteses dentárias. ${ }^{290}$ Ou seja, foi revogado este direito sob o argumento de que assim estes indivíduos teriam mais auto-responsabilidade na prevenção. Paralelamente às restrições, foram introduzidas medidas odontológicas profiláticas que viriam atenuar déficits de qualidade da atenção.

Outra medida incluída no pacote de economia (Sparpaket) consistiu na limitação das ações preventivas adicionais e de promoção da saúde oferecidas pelas Caixas, como os cursos para parar de fumar ou hidroginástica, programas educacionais ou subsídios para grupos de auto-ajuda. Apenas as medidas preventivas de maior necessidade continuaram a ser financiadas pelas Caixas. Medidas preventivas já regulamentadas e de diagnóstico precoce para grávidas, crianças e câncer, profilaxia dentária, vacinas, e check-ups permaneceram. Este corte é digno de nota, pois a exclusão do catálogo fez com que inúmeras iniciativas positivas de prevenção e promoção, introduzidas após a lei da reforma de 1988, fossem abortadas, ainda que supostos abusos com medidas de promoção da saúde possam ter sido identificados (Stegmüller, 1996b).

A inclusão desta lei como contribuição do Ministério da Saúde às medidas de contençāo do Sparpaket significou a ruptura de acordo anterior de disposição para a negociação. Os social-democratas, em certo momento, mostraram-se propensos à negociaçāo para a aprovação da terceira etapa da reforma do sistema de seguro social de saúde. Todavia, após o lançamento do 'pacote', o SPD passou a exigir, como condição para participar das negociações, que as leis fossem agrupadas e negociadas em conjunto, o que significaria a possibilidade de alteração do Sparpaket. Sem essa junção, o SPD negou-se peremptoriamente a participar da aprovação das outras leis para a terceira etapa (Süddeutsche Zeitung, 26.06.96).

Apesar dos protestos e de demonstrações maciças contra o 'pacote' organizadas pela Central Sindical (DGB) em diversas cidades, a coalizão governamental fez valer sua maioria no Parlamento (Bundestag) (FR.,08.09.96). Em 13 de setembro de 1996, o pacote foi aprovado e, com ele, a Lei de Alívio das Contribuições, por diferença de apenas quatro votos (TAZ, 14/15.09.96).

Os resultados do principal corte introduzido pela lei - redução no auxílio financeiro por afastamento do trabalho em caso de doença - fizeram-se notar de modo imediato. Em 1997, ocorreu declínio dos gastos do GKV com auxílio-doença e redução do número de dias de afastamento por motivo de doença (Sozialpolitische Umschau, 269/1997). Quanto aos salários pagos pelo empregador nas seis primeiras semanas de dispensa do trabalho por motivo de doença, o nível dos benefícios foi mantido nos acordos coletivos, na grande maioria dos ramos de produção, diante da forte resistência dos trabalhadores: operações-tartaruga, greves, manifestações de porta de fábrica e passeatas(FR, 25 e 26.09; 30.09; 04.10;10.10 e 06.12.1996).

290 Note-se que, no Brasil, a maioria das ações cortadas não é coberta sequer pelos seguros privados. 
Os trabalhadores ligados ao DGB mostraram-se firmes na defesa da continuidade do pagamento de salários integrais em caso de doença, o que produziu resultado positivo. Avaliações das negociações de acordos coletivos no ano evidenciaram que a maioria dos trabalhadores garantira a continuidade do pagamento de $100 \%$ dos salários nas primeiras seis semanas de licença por doença pelos empregadores e que, em alguns setores, fora assegurado mesmo a complementação da perda parcial do auxílio-doença pago pelas Caixas, também reduzido pelo 'pacote de economia' (Bispinck, 1997; FR, 21.05.97). ${ }^{291} \mathrm{Em}$ geral, apenas profissões de menor importância tiveram seus benefícios reduzidos conforme a lei.

Os resultados da implementação dos cortes do auxílio-doença definidos pela lei mostram que, à medida que o padrão legalmente estipulado é reduzido, amplia-se o campo para retorno de privilégios. São reatualizadas as desigualdades de direitos/benefícios entre categorias profissionais/ramos da produçāo conforme sua importância no processo de acumulação e grau de organização política, característica do modelo meritocrático-corporativo de proteção social.

Com a promulgação do'pacote econômico', a situação de disputa entre Caixas e governo agravou-se. As Caixas se posicionaram contra as medidas, tidas como falsos mecanismos de condução, e recusaram a possibilidade de reduçāo das taxas de contribuição imposta pela lei. Ainda em 1996, pressionaram por aumentos das taxas de contribuição, tidos como imprescindíveis face aos déficits contabilizados.

\section{Leis de Reordenação do Seguro Social de Doença}

Ao final de setembro de 1996, logo após a promulgação da Lei de Alívio das Contribuições, a coalizão governamental divulgou nova proposta para a continuação da terceira etapa da reforma do Segure Social de Doença (CDU/CSU/ FDP, 1996c). Esta substituiu os dois projetos de lei anteriores rejeitados pelo Conselho Federal (Bundesrat) por alterarem competências das unidades federadas, de cuja concordância obrigatória dependiam.

A nova proposta governamental, composta pelos projetos das Leis 1 e 2 para Reordenaçāo da Administração Autônoma e da Responsabilidade Própria no Seguro Social de Doença (GKV-Neuordnungsgesetz, 1. und 2. NOG), foi formulada de modo a dispensar a aprovação pelo Conselho Federal (Bundesrat), podendo, para tanto, a coalizão governamental fazer valer sua maioria no Parlamento (Bundestag) para aprovação.

291 A garantia dos pagamentos, porém, na maioria dos casos, resultou de algum tipo de compensação pelos empregados. 
Seguindo o estilo das leis de contenção de gastos anteriores, a legislação teve como objetivo principal a estabilização das taxas de contribuição. A coalizão governamental justificou as medidas como necessidade de limitação dos custos sociais do trabalho para melhoria da situaçāo das empresas alemãs na competição internacional e a redução do nível de desemprego.

As justificativas imediatas para a intervenção governamental foram os repetidos déficits do Seguro Social de Doença (GKV) e o anúncio feito por diversas Caixas acerca da elevação das taxas de contribuiçāo em conseqüência disso. Em 1995, o sistema apresentou déficit de 7,0 bilhões de marcos e, em 1996, de 6,8 bilhões (Quadro 4). Para o governo, estes déficits seriam decorrentes da falta de responsabilidade financeira das Caixas, que ultrapassaram seus orçamentos em diversos setores (Bundesregierung, 1996).

Com a terceira etapa da reforma, o governo pretenderia efeitos mais duradouros, colocando a estabilização das taxas de contribuição definitivamente sob a responsabilidade dos parceiros da administração autônoma. As regulamentações excessivas seriam abolidas. Apenas o "estritamente necessário seria regulado por lei, permanecendo somente os 'instrumentos de condução adequados para o controle da dinâmica dos gastos” (Bundesregierung, 1996:44). Argumentava assim ter por meta o fortalecimento das áreas de administração autônoma do sistema, o que estaria de acordo com o princípio da subsidiariedade, pois a vigência deste princípio implicaria na precedência da Administração Autônoma sobre a ação estatal direta.

A coalizão governamental mostrou-se avessa a qualquer negociação das Leis de Reordenação do GKV (NOG) com a oposição. Desse modo, a expectativa de que a terceira etapa da reforma resultaria de processo de negociação e acordos não se concretizou. Embora o período de discussão da terceira etapa tenha sido longo, o processo não foi de afinamento progressivo de propostas até a produção de acordo. Ao final, a coalizão governamental fez valer sua maioria parlamentar. Apresentou projetos, elaborados de modo a dispensar qualquer acordo com a oposição no Conselho Federal (Bundesrat), que foram aprovados com poucas alteraçōes, o que significa mudança no modo negociado em que o processo de reforma vinha sendo encaminhado.

$\mathrm{Na}$ etapa anterior, a estratégia governamental para o aprofundamento das medidas de contenção havia sido a busca de consenso entre experts e de apoio do partido social-democrata, o que levara à introduçāo de importantes mudanças nas propostas governamentais apresentadas originalmente.

As Leis de Reordenação (1. e 2. NOG) definiram mecanismos drásticos de coação contra aumentos das taxas de contribuição, possibilitaram diversificação de contratos com segurados, aboliram regulamentações prévias e introduziram importantes restrições no catálogo de serviços, em especial ao tornar opcionais 
parte das ações prestadas por outros profissionais não médicos, proposição posteriormente excluída da lei, além de medidas específicas para os diversos setores de atenção (Quadro 8). ${ }^{292}$

Uma das leis promulgadas (1. NOG) vinculou os aumentos das taxas de contribuição por parte das Caixas à majoração automática e compulsória dos valores de co-pagamento vigentes e definiu regra especial para desligamento da Caixa, possibilitando o desligamento imediato do segurado no caso de elevação da taxa de contribuição. ${ }^{293}$ Alterou ainda as regras para dispensa de co-pagamento para pacientes crônicos (Bundestag, 1997a).

\section{Quadro 8 - Principais medidas das Leis de Reordenação do GKV (1. 2. GKV-Neuordnungsgesetz) de 1997}

\begin{tabular}{|c|c|}
\hline $\begin{array}{l}\text { Restrições da } \\
\text { autonomia das } \\
\text { Caixas }\end{array}$ & $\begin{array}{l}\text { A elevaçăo das taxas de contribuição é acoplada à majoração automática e } \\
\text { compulsória dos valores de co-pagamento; }\end{array}$ \\
\hline Regras adscrição & $\begin{array}{l}\text { Regra especial para mudança de Caixa, no caso de aumento das taxas de } \\
\text { contribuição; }\end{array}$ \\
\hline $\begin{array}{l}\text { Opçōes para } \\
\text { contratos } \\
\text { diferenciados } \\
\text { com segurados }\end{array}$ & $\begin{array}{l}\text { Franquia: assunção de percentagem dos gastos pelos segurados em contra- } \\
\text { partida a taxas de contribuição mais baixas; } \\
\text { Recompensa monetária pela não utilização; } \\
\text { Restituição de despesas; }\end{array}$ \\
\hline $\begin{array}{l}\text { Restriçōes no } \\
\text { catálogo }\end{array}$ & $\begin{array}{l}\text { Aumentos de co-pagamento em } 5 \text { DM ou } 5 \text { pontos percentuais; reajustes } \\
\text { bianuais; } \\
\text { Novas restriçōes para próteses dentárias (exclusão de implantes e coroas } \\
\text { de cerâmica); } \\
\text { Introdução de participação financeira dos segurados em } 20 \% \text { para alguns } \\
\text { meios de ajuda (bandagens, meias de compressão); } \\
\text { Possibilidade de novas modalidades de co-pagamento para áreas de } \\
\text { geriatria e tratamento para dependência de drogas; }\end{array}$ \\
\hline
\end{tabular}

(continua)

292 É extensa a segunda Lei de Reordenação (2.NOG), contando com 19 artigos que alteram quase cem parágrafos da legislaçăo da área da saúde; entre estas, há 57 alterações do V Livro do Código Social (V SGB). Para maiores detalhes acerca do conteúdo das leis, consulte Giovanella, 1998.

293 Para cada 0,1 ponto percentual de aumento nas taxas de contribuição, as Caixas deveriam majorar em 1 marco os valores de co-pagamento para medicamentos, internaçōes hospitalares, estadas em casa de restabelecimento (Kurhaus) e transporte de doentes. No caso de copagamentos definidos em percentagens de participaçăo dos usuários nos gastos, estes aumentariam em um ponto percentual. 


\begin{tabular}{|c|c|}
\hline $\begin{array}{l}\text { Outras altera- } \\
\text { ções no catálogo }\end{array}$ & $\begin{array}{l}\text { Novas medidas de profilaxia na atenção odontológica; } \\
\text { Regulamentação da cobertura para pacientes terminais em regime } \\
\text { de internação; }\end{array}$ \\
\hline $\begin{array}{l}\text { Desregula- } \\
\text { mentação }\end{array}$ & $\begin{array}{l}\text { Abolição dos tetos orçamentários, atenção ambulatorial, medicamen- } \\
\text { tos c 'outros métodos terapêuticos' c negociação do orçamento } \\
\text { indicativo; abolição plano de equipamentos de grande porte; } \\
\text { Abolição de regra de definição da neccssidade de recursos humanos } \\
\text { no setor hospitalar; }\end{array}$ \\
\hline $\begin{array}{l}\text { Regulamen- } \\
\text { tação }\end{array}$ & $\begin{array}{l}\text { Ampliação das compctências Comissão Conjunta de Médicos c Caixas } \\
\text { no planejamento de necessidades e no modelo de parcerias para } \\
\text { outros métodos terapĉuticos, cuidados domiciliares, Kur, reabilitação; } \\
\text { Ampliação das competências das Caixas e hospitais no desenvolvi- } \\
\text { mento dos pagamentos prospectivos diagnóstico-relacionados; } \\
\text { Definição de teto orçamentário para gastos hospitalares acoplado à } \\
\text { evolução das receitas de contribuição; redução escalonada de paga- } \\
\text { mentos em caso de ultrapassagem de orçamcntos; } \\
\text { Mudanças na remuneração médica: tetos de gastos por consultórios } \\
\text { Praxisbudget; } \\
\text { Redefinição do limite de acomctimento da renda familiar para parti- } \\
\text { cipação financeira de segurados c regra especial para paciente crônico; } \\
\text { Definição de valor fixo para prótescs dentárias substituindo a resti- } \\
\text { tuição de despesas; }\end{array}$ \\
\hline $\begin{array}{l}\text { Inovaçōes na } \\
\text { organização da } \\
\text { atençāo }\end{array}$ & $\begin{array}{l}\text { Possibilidade de cmprcender projetos pilotos de novos modelos de } \\
\text { organização da prestação c de formas de remuneração; } \\
\text { Novas formas de organização da atenção: modelo assistencial segun- } \\
\text { do o qual o clínico geral ou consultórios associados em rede, cscolhidos } \\
\text { pclo segurado, responsabilizam-se pcla garantia de atenção e pela } \\
\text { qualidade e cficiência da atenção ambulátorial prestada, assim como } \\
\text { pelo todo ou parte das prescriçōes e encaminhamentos solicitados. }\end{array}$ \\
\hline
\end{tabular}

A outra Lei de Reordenação (2.NOG) aumentou imediatamente os valores de co-pagamento em cinco marcos, maior aumento até então proposto, e ampliou as possibilidades das Caixas no estabelecimento de contratos diferenciados com os segurados, introduzindo alguns procedimentos típicos de seguro privado. Os segurados poderiam optar: pelo reembolso de despesas, pela restituiçāo de parcela de contribuição como prêmio por baixa utilização e pela assunçāo de percentagem predefinida dos gastos. Estes mecanismos seriam opções para as Caixas em competiçāo atraírem segurados. Servem, entretanto, à seleção de riscos, pois a competição por segurados não é apenas para manter uma fatia de mercado, mas, 
em especial, para atrair uma parcela de segurados de baixo risco. A competição é, antes de tudo, competição pelos bons riscos, o que é facilitado por meio destes mecanismos, podendo induzir segmentaçāo de clientelas.

Para a coalizão governamental conservadora-liberal, o setor hospitalar deveria passar 'definitivamente a assumir sua parte de responsabilidade na estabilização dos gastos'. Pela lei, a evolução dos gastos hospitalares foi mais rigidamente controlada, sendo definido teto para gastos setoriais. A possibilidade de majoraçāo de orçamentos hospitalares e de preços dos procedimentos foi atrelada à evolução das receitas das Caixas e não mais à evolução dos salários do setor público como até então. Como auxílio de emergência (Notopfer), para a conservaçāo dos hospitais foi introduzida contribuição anual de 20 marcos a ser paga pelos segurados nos próximos três anos (Bundesregierung, 1996).

Sob o mote da desregulação/desestatização (Entstaatlichungsmassnahmen), diversas regras legalmente definidas foram abolidas, e a responsabilidade pelas mesmas, transferidas para os parceiros da administração autônoma. $O$ plano de equipamentos de grande porte ${ }^{294} \mathrm{e}$ a regra para definição da necessidade de recursos humanos em hospitais foram abolidos. O desenvolvimento do sistema de pagamento hospitalar, a ampliação do catálogo de diagnósticos e procedimentos para o pagamento prospectivo de valores globais por paciente internado também passaram a ser atributo conjunto de Caixas e hospitais (Bundesregierung, 1996). ${ }^{295}$ Os tetos orçamentários fixos para gastos com medicamentos, atenção ambulatorial e outros métodos terapêuticos foram substituídos por indicativos negociados. Deveriam ser negociados entre médicos e Caixas tetos financeiros orientadores (Richtgrösse) por especialidade para o conjunto dos gastos desencadeados pelos médicos - medicamentos, outros métodos terapêuticos (Bundestag, 1997b).

A abolição desses tetos orçamentários significou importante ganho para os médicos, pois foram abolidas algumas das sanções coletivas pela ultrapassagem dos orçamentos para prescrições e o valor da unidade de serviço voltou a ser previamente fixado. A condição colocada pelo governo para a abolição do limite de gastos ambulatoriais foi a definição de sistema de pagamento que controlasse a expansão do volume de ações, com contra-incentivos à expansão, o que foi contemplado em novo sistema de pagamento, que definiu valores médios de unidades de serviço a serem pagas por caso tratado, denominado Praxisbudget. Incor-

294 Segundo o plano de equipamentos de grande porte, vigente desde 1990 , a cobrança pelos prestadores de ações relativas à utilização destes equipamentos só poderia ocorrer com o consentimento prévio da Comissão Estadual especílica que se posicionava sobre a distribuiçāo regional e equilibrio da oferta desses equipamentos entre os setores hospitalar e ambulatorial (BMAS, 1994).

29.5 Caso as Associações das Caixas e dos hospitais nāo entrem em acordo, uma nova comissão de arbítrio foi prevista. 
porada na última hora, à lei, a mudança do sistema de remuneração ambulatorial fora acordada setorialmente (Bundestag, 1997b). ${ }^{296}$

Foi prevista maior competência da Comissão Federal Conjunta de Médicos Credenciados e Caixas, juntamente com os prestadores específicos, na definição de açôes e orçamentos para diversos setores assistenciais, tais como: outros métodos terapêuticos, cuidados domiciliares, Kure açōes de reabilitaçāo. O objetivo da medida seria combater as elevadas taxas de crescimento de gastos nestes âmbitos nos últimos anos. Com tal mecanismo, a coalizão governamental pretendeu concretizar a competência da (Bundesausschuss der Ärzte und Krankenkassen) Comissão Federal Conjunta de Médicos Credenciados e Caixas quanto à prescrição destas ações. Ao mesmo tempo, o procedimento proposto permitiria maior participação das organizaçōes dos prestadores nas decisões pertinentes a suas áreas de competência. A partir da vigência da lei, as Associações Federais das Caixas e as associações dos prestadores específicos - fonoaudiólogos, massoterapeutas, fisioterapeutas e outros - passariam a acordar recomendaçōes gerais para garantia da qualidade e eficiência da prestaçāo dos serviços em pauta. Negociações estas nas quais os médicos tomam parte.

Com esta medida, a responsabilidade a respeito da garantia destas ações é transferida em grande parte para as Caixas e prestadores. Expande-se o modelo corporativo da prestação ambulatorial médico-odontológica a outras áreas da atenção, ao mesmo tempo em que se fortalece a posiçāo dos médicos ao interior do sistema de atenção.

A coalizāo governamental, para justificar suas medidas, argumentou estar fortalecendo princípios básicos do GKV. Os princípios de 'administração autônoma' e de 'subsidiariedade' implicariam, segundo o governo, a precedência da 'responsabilidade' dos participantes relativa à regulamentação estatal, e este seria um dos propósitos da terceira etapa.

Para evitar que a maior liberdade das Caixas produzisse explosão de gastos e conseqüente aumento das taxas de contribuição, seria necessário fortalecer a 'responsabilidade' financeira das Caixas, obrigando-as a alocar economicamente os recursos a sua disposição e a autorizar apenas as ações necessárias. $\mathrm{O}$ acoplamento da decisão de uma Caixa quanto ao aumento da taxa de contribuição ao acréscimo compulsório dos valores de co-pagamento e o direito especial de rescisão de contratos pelos segurados seriam as barreiras adequadas que obrigariam as Caixas a utilizar seus recursos de modo parcimonioso e a negociar contratos mais favoráveis. "A combinação entre maior grau de liberdade das Caixas, competição entre elas e liberdade de escolha para os segurados criaria condições básicas para que as Caixas lidassem de forma responsável com o dinheiro dos segurados" (Bundesregierung, 1996:45).

296 A reforma do sistema de remuneração médica foi incluída na lei, talvez como garantia de cumprimento do acordo. 
Para o Ministério da Saúde, a medida estimularia o movimento de segurados, favorecendo a competição entre Caixas. Com este duplo mecanismo, por temor de perda de segurados e de colocar em risco sua própria existência, as Caixas seriam obrigadas a evitar ao máximo os aumentos das contribuições. ${ }^{297} \mathrm{O}$ acréscimo dos valores de co-pagamento teria efeito de mobilização dos segurados maior do que apenas o aumento das taxas de contribuição. Os segurados, em geral, têm certa lealdade a sua Caixa e desconhecem o quanto pagam de contribuição (pois é descontada no salário, tal como nossa contribuição previdenciária), mas são obrigados a pagar o valor do co-pagamento para medicamentos cada vez que aviam uma receita na farmácia, por exemplo. ${ }^{298}$ Desse modo, segundo o argumento governamental, aumentos automáticos no co-pagamento seriam estímulo eficaz para os segurados mudarem de Caixa.

Embora esta restrição seja logicamente construída, năo atinge o cerne da questão: problemas estruturais do financiamento e déficit de condução na prestação. A introdução do mecanismo proposto resultaria em dupla penalidade dos segurados e, em particular, dos pacientes. Estes tanto pagariam taxas de contribuição mais altas como quantias maiores quando da utilização dos serviços. Além disso, esse mecanismo coercitivo poderia vir a impor às Caixas, a médio prazo, a necessidade de introduzirem restrições à utilização de determinadas ações a fim de evitar aumentos nas taxas de contribuição.

Pelo tipo de medida proposta, subentende-se que, para a coalizão governamental, as Caixas disporiam de altas reservas de economicidade, estando em condições de evitar os repetidos déficits sem ter de recorrer a aumentos das contribuições. Contudo, boa parte do déficit é causado por excessivos gastos com medicamentos, para os quais nenhuma recomendação ou controle foi contemplada nessas leis. A elaboração de lista positiva, definida na Lei da Estrutura da Saúde (GSG), não foi retomada.

Com o mecanismo coercitivo, somado às outras medidas restritivas, o governo tentou retirar-se do cenário, obrigando as Caixas em competiçāo a controlar taxas e gastos por meio de mecanismos coercitivos para garantir sua sobrevivência, e estipulou um nível mínimo de privatizaçăo, visando a evitar ônus para os empresários.

Torna-se assim transparente o significado para a 'reordenação da responsabilidade própria dos segurados’. Responsabilidade implica maior participação

297 O partido liberal (FDP) e o ministro da Saúde Seeofer chegaram a propor, como alternativa ao aumento compulsório dos valores do co-pagamento, a opçāo pelo congelamento da parcela da taxa de contribuição paga pelos empresários, o que significaria assumir a despedida imediata e transparente do financiamento paritário. A proposta não foi aceita nem ao interior da coalizão governamental, mas serviu como ameasa para garantir o apoio dos descontentes ao mecanismo coercitivo e ao aumento dos valores de co-pagamento.

298 Os segurados criticam mais os aumentos nos valores de co-pagamento do que as majoraçōes das taxas de contribuição (Ulrich, Wemken \& Walter, 1994). 
financeira direta dos pacientes nos gastos: deslocamento de gastos do financiamento paritário para os domicílios privados. Além disso, a regra que obriga as Caixas a aumentarem os montantes de co-pagamento, as induz a procederem uma seleção de riscos, ou seja, a encontrar todas as formas para atrair os 'melhores riscos' e garantir balanço favorável.

As propostas da coalizão governamental foram muito criticadas, mas mesmo assim a maioria delas permaneceu na lei aprovada. Os críticos mais contundentes viram no novo pacote da coalizão governamental o desmonte do sistema de seguro social de saúde: seu princípio básico de solidariedade estaria sendo ferido e haveria o perigo de uma americanização do sistema de saúde alemão. Elevação nas taxas de contribuiçāo, cortes no catálogo, aumento progressivo da participação dos segurados nos gastos, segmentação de clientelas, atençāo recebida conforme as possibilidades financeiras individuais foram as tendências prognosticadas. Aumento da participação dos gastos de saúde como proporção do PIB e nível de saúde mais baixo seriam as últimas conseqüências (Steffen, 1996a).

A maioria dos principais atores setoriais posicionou-se contra a nova proposta da coalizão governamental. A Central Sindical (DGB - Deutscher Gewerkschaftsbund) repudiou fortemente a lei. As justificativas básicas apresentadas eram de que os princípios fundamentais do sistema de seguro social, solidariedade, necessidade e financiamento paritário, seriam atingidos, ao mesmo tempo em que não incluiria efetivas respostas aos problemas existentes (DGB, 1996b; DGB, 1996c). Empregadores e pessoas saudáveis seriam beneficiados; os doentes, prejudicados. A reduçāo dos gastos financiados paritariamente teria como preço o aumento dos gastos financiados individualmente pelos segurados (DGB, 1996c).

Os médicos credenciados inicialmente lançaram nota conjunta com as Caixas, criticando a primeira das duas leis aprovadas (1.NOG). Concordaram com o objetivo de estabilização das taxas de contribuição por meio da renúncia a ações médicas desnecessárias e de mudanças no sistema de saúde. Contudo, os instrumentos apresentados no projeto de lei não seriam adequados. Outros caminhos deveriam ser buscados. Caixas e médicos credenciados dispor-se-iam a trabalhar conjuntamente para o desenvolvimento competitivo da estrutura de atenção, a exploração das reservas de racionalidade do sistema e a melhoria da qualidade da atenção, evitando ações desnecessárias e promovendo inovações na organização da atençāo (KBV \& Spitzenverbände der Krankenkassen, 1996).

Nesta nota, Caixas e Médicos consideraram que a obrigatoriedade de aumento do co-pagamento a cada elevação das taxas de contribuição seria injusta para os pacientes, os quais viriam a ser tratados desigualmente, de forma arbitrária, por uma ou outra Caixa. Por um lado, o direito à rescisão do contrato em curto prazo, por parte do segurado, nāo seria suficiente para minimizar a arbitrariedade, pois os contribuintes consideram a possibilidade de mudança de 
Caixa apenas em último caso. Por outro lado, a majoração do co-pagamento não ocorreria necessariamente nas mesmas áreas da atenção responsáveis pela elevação das contribuições. ${ }^{299}$

Os empregadores declararam-se imediatamente favoráveis por meio do posicionamento da Federação Nacional das Associaçōes de Empregadores Alemães (BDA, 1996). A Associaçāo de Empregadores saudou o projeto de lei governamental para estabilizaçāo das taxas de contribuição do GKV. Demonstrou seu apoio ao acoplamento entre aumento das contribuições, co-pagamento e direito especial de rescisão de contratos, considerando-o mecanismo adequado de condução. A proposta governamental levaria, segundo a Federação de Empregadores, ao fortalecimento da administração autônoma, à ampliação da auto-responsabilidade dos segurados e à intensificação da competição.

\section{A estratégia conservadora-liberal}

As leis aprovadas baseiam-se em uma concepção da competição aqui denominada 'privatização da demanda', em concordância com Gerlinger \& Stegmüller (1995b). Nesse caso, a competição expressa a perspectiva da privatização parcial da cobertura ao risco de adoecer. O que significa dizer que a reforma aprovada, além de reduzir a competição à concorrência entre as Caixas por segurados e em detrimento daquela entre os prestadores, concede prioridade a medidas de 'incentivo à racionalização do comportamento da demanda'.

Nessa tipologia podem ser enquadrados o co-pagamento em seus diversos aspectos, o estabelecimento de franquias e o bônus pela baixa utilização. Considera-se aqui adequada a qualificação 'privatização da demanda', atribuída à reforma aprovada, pois a ampliação do co-pagamento é a medida central da proposta, menos pela majoração imediata - tão elevada que isoladamente é suficiente para cobrir mais da metade do déficit existente - e mais por ser o mecanismo principal para coibir a elevaçāo das taxas de contribuição. A obrigatoriedade de elevação do co-pagamento é usada como sanção para o caso de majoração das taxas de contribuição. Nesse sentido, o co-pagamento torna-se mecanismo coercitivo para a estabilização das taxas de contribuição.

A lei aprovada incluiu também medidas que podem ser consideradas como de 'racionalização da oferta', em especial as relativas ao sistema de pagamento das prestaçōes sanitárias ambulatoriais e aquelas referentes às possibilidades de mo-

299 Uma semana após esta nota conjunta, um representante da Federação das Associações de Médicos das Caixas (KBV) manifestou apoio à proposta governamental, exigindo maior participaşão financeira dos segurados e acusando as Caixas de pretenderem a seleçāo de riscos (FR, 15.11.96). Para as Caixas, a nova posição da KBV seria uma forma de tentar encontrar aliados no governo para a disputa relativa ao orçamento de medicamentos então em pauta. 
dificação das formas de organização da atenção. Ainda que de modo pouco abrangente, as leis facilitam a diferenciação dos contratos das Caixas com os prestadores por meio da experimentação de novos modelos de organização, financiamento e remuneração, como também pelas chamadas novas 'estruturas organizacionais'. Em ambos os casos, os contratos somente poderão ser negociados com as Associaçōes de Médicos das Caixas, restringindo bastante as possibilidades de diversificação.

A tentativa de implementação de novos modelos que permitem desvios da legislação em vigor, por sua vez, é restrita a projetos pilotos de prazo limitado. Já as formas inovadoras de 'estruturas organizacionais da atençāo', modelos do médico generalista (Hausarztmodell), e consultórios em rede (Vernetzen Praxen) sāo definidas na lei e admitem menos flexibilidade. A experimentação destas inovaçōes é permitida apenas no contexto de estabilização das taxas de contribuiçāo, devendo concorrer para tal. Com alguns pressupostos similares ao modelo de managed care americano, estas novas formas organizacionais podem vir a ser difundidas como estratégia das Caixas em competiçāo para oferecer preços baixos e garantir sua parte no mercado, tendendo a imprimir mudanças no modelo assistencial.

Outra série de medidas aprovadas pode ser qualificada de 'desregulação' e de deslocamento de competências para a administração autônoma. Assim, certas formas de controle legal foram diretamente abolidas e, simultaneamente, várias responsabilidades foram transferidas para a Comissão Conjunta de Médicos e Caixas. Assim, o controle passou a ser responsabilidade da administração autônoma em diversos aspectos da atenção, deixando de ser definido pela legislação.

A principal mudança em termos de 'deslocamento de competências' foi a expressiva ampliaçāo das responsabilidades da Comissão Federal Conjunta de Médicos Credenciados e Caixas. Essa Comissão, existente há mais de 75 anos, é a responsável pela definição concreta do catálogo de serviços. Sua atuação, porém, tem sido mais no sentido de discutir a inclusão de inovações do que de avaliar a assistência individual curativa e as condutas médicas. ${ }^{300}$ Além de assumir responsabilidades em substituição à parte das regulamentações abolidas, essa Comissão tem competências ampliadas em diversos aspectos da atenção. Suas diretrizes e decisões conformarão o fundamento da homogeneidade e uniformidade no GKV.

Se é verdade que se ampliam os espaços de atuação da chamada administraçăo autônoma simultaneamente à retração das responsabilidades do Estado,

300 A Comissão Conjunta de Médicos e Caixas atua por meio de comissões específicas por assunto. Atualmente existem dez comissões específicas: 'tratamento médico', 'prevenção', 'planejamento familiar', 'medicamentos', 'outros métodos terapêuticos', 'meios de ajuda', 'cuidados domiciliares', 'reabilitaç̃̃o incapacidade para o trabalho', 'planejamento de necessidades', avaliação de qualidade', 'psicoterapia' e 'hospital'. Foram elaboradas dezesseis diretrizes (oito delas nos anos 90 ) relativas a aspectos dos âmbitos de atuação dessas comissōes específicas, mas nenhuma referente ao tratamento médico. 
esse processo é em si mesmo comandado pelo Estado ao definir as condiçöes da atuação da administração dentro de limites estritos de contenção. A responsabilidade pública transferida para provedores e prestadores reforça o esquema (neo)corporativo característico da organização do seguro social de doença alemão, mas são definidas, ao mesmo tempo, condições estritas para sua atuação. Em síntese, transferem-se competências para outros agentes de regulação e redefinemse os propósitos e objetivos da regulação. ${ }^{301}$

A delegação de competências estatais aos órgãos de administração autônoma conjunta não significa que tenham sido ampliados diretamente os espaços de negociação e os graus de liberdade de ação destes organismos. As possibilidades de ação são canalizadas de antemão de acordo com os objetivos políticos da coalizão governamental. A política estatal contém uma série de precauções/dispositivos legais capazes de garantir que a introduçāo da competição incorra na privatização do risco de adoecer e que os interesses dos prestadores nāo sejam substancialmente refreados. A renúncia ao esgotamento de todas as reservas de economicidade e ao potencial de racionalização do sistema, ${ }^{302}$ um dos itens da perspectiva política liberal conservadora, foi, por sua vez, clientelisticamente motivada $^{303}$ (Gerlinger, Giovanella \& Michelsen, 1997). ${ }^{304}$

Com a lei da 'terceira etapa da reforma da saúde' intensificou-se a competição entre as Caixas em contexto financeiro restrito, induzindo-as indiretamente a implementar estratégias para seleção de riscos e de restriçōes no volume de açōes oferecidas. Deste modo, o Estado intervém diretamente na modelagem do GKV por caminhos administrativos. Assim, não é possível falar apenas em 'corporativização' do sistema de saúde, ou em 'precedência para administração autônoma', poís este conceito obscurece a dimensão da política conservadoraliberal de direcionamento das ações dos atores. O Estado, como arquiteto da ordem política, transfere competências às caixas e associaçōes de médicos credenciados - organizações de direito público -, porém, define os limites e âmbito em que a ação pode se desenvolver de forma rígida e detalhada.

301 A vigilância estatal permanece por meio de diversos mecanismos e órgãos. Mas, em termos analíticos, poder-se-ia dizer que a vigilância não se exerce sobre a finalidade de 'interesse geral', de garantia de proteção social como aquela do 'Estado nacional keynesiano'. A vigilância principal é efetuada sobre a estabilização das taxas de contribuiçāo. É vigilância concernente à garantia dos interesses econômicos de um 'Estado competitivo nacional' (nationalen Wettbewerbsstaat) (Alvater, 1994a).

302 Embora o ministro da Saúde mencionasse, alguns meses antes da reforma, uma potencialidade de economia no sistema de cerca de 25 milhōes de marcos por meio de regulação da prestação, ao final, a opşão foi a ampliação das receitas por meio do co-pagamento (Schönbach, 1997).

303 Resguardando-se interesses dos médicos e da indústria farmacêutica, por exemplo.

304 Antes de tudo, as decisōes resultam de claras opções políticas; não são exigência econômica. 


\section{Lei da Reforma do Seguro Social de Doença 2000}

A coalizão social-democrata/verdes, logo após a sua vitória eleitoral, em outubro de 1998, desencadeou nova fase de reformas do setor saúde. Ainda em 1998, acordou a revogação das principais restrições introduzidas nas leis da terceira etapa e em 1999 foi aprovada nova legislação setorial.

A ministra da Saúde, Andrea Fischer, do Partido Verde, apresentou, em novembro de 1998, como legislação de 'partida', a Lei para o fortalecimento da solidariedade no GKV (Gesetz zur Stärkung der Solidarität in der GKV-Vorschaltgesetz), tornando sem efeito as mais importantes restriçōes introduzidas com a 'terceira etapa' e definindo regulamentações de curto prazo.

Após pequenas reformulações, a lei foi aprovada no parlamento pela coalizão governamental que contava com a maioria no Conselho Federal (Bundesrat), tendo entrado em vigor em janeiro de 1999 . O novo governo, desse modo, sinalizou estar cumprindo promessas de campanha. A nova legislação derrubou mudanças estruturais de caráter neoliberal, introduzidas pelo governo anterior sob pressão de seu parceiro de coalizão, o partido de inclinação liberal (FDP) (Deppe, 2000).

A legislação englobou três tipos de medidas: 1) delimitação de gastos: a lei condicionou o aumento de despesas à evolução das receitas de contribuição e fixou tetos orçamentários para gastos em todos os setores de atenção; 2) redução do copagamento e das restrições de benefícios: foi reintroduzida a cobertura de próteses dentárias para nascidos após 1978, abolido o mecanismo referente ao aumento compulsório dos valores de co-pagamento no caso de elevação das taxas de contribuição pelas Caixas, reduzidos os valores de co-pagamento para medicamentos ${ }^{305}$ e eliminado o co-pagamento para sessões de psicoterapia; 3) abolição de elementos do seguro privado: a lei suspendeu a possibilidade de introdução de franquias, restituição de despesas e pagamento de bônus (Am Orde, 1999).

De modo concomitante à provaçāo da lei, iniciou-se a discussāo para a 'Reforma 2000'. Estiveram em discussão medidas relativas à reorganização do sistema de atenção e à definição de teto orçamentário para o GKV. Entre as propostas de mudanças no modelo assistencial, destacam-se o fortalecimento do papel dos clínicos gerais na coordenação da atenção e diversos estímulos à maior cooperaçāo entre clínicos gerais e especialistas e à articulação entre os setores ambulatorial e hospitalar. No centro da agenda pública esteve o debate de um orçamento global (Globalbudget). Discutiu-se ainda reordenaçāo do mercado farmacêutico, reformas na formação médica, melhor controle sobre as especialidades médicas (Am Orde, 1999).

305 Valores reduzidos para 8, 9 e $10 \mathrm{DM}$, anteriormente elevados para 9, 11 e $13 \mathrm{DM}$, de acordo com o tamanho da embalagem. 
Na discussão da nova reforma, enquanto a Central Sindical (DGB) e as Caixas posicionaram-se de modo favorável, formou-se forte resistência por parte dos empresários, indústria farmacêutica, hospitais, farmácias e especialmente por parte da corporação médica. ${ }^{306}$ Esta mobilização manteve-se contínua durante toda a fase de elaboração da nova proposta governamental para a Reforma da Saúde 2000, cujas diretrizes foram apresentadas em março de 1999 e encaminhadas ao parlamento.

Em novembro de 1999, o Conselho Federal (Bundesrat), no qual no entremeio a coalizāo governamental perdera a maioria, rejeitou o projeto de lei, tendo todos os 16 estados da Federação votado contra: os governos de oposição por críticas ao conteúdo da lei e os governos da coalizão social-democrata-verde por conta de questões formais de apresentação do texto.

Após a derrota no Bundesrat, nova versão da lei foi enviada ao parlamento, tendo sido elaborada legislação em separado a respeito de compensação financeira de estrutura de riscos para a Alemanha como um todo. Desse modo, a Lei da Reforma do GKV 2000 ( $G K V$ - Gesundheitsreformgesetz 2000) foi aprovada pela maioria no Parlamento (Bundestag), em 16 de dezembro de 1999. A Lei para Adaptação do Direito no Seguro Social de Doença, unificando a compensação financeira da estrutura de riscos até então separada para as regiōes ocidental e oriental foi aprovada no Conselho Federal em 17 de dezembro com o apoio dos governos democrata-cristãos da região oriental; por conta dos importantes aportes financeiros, daí decorrentes para esta região. As leis aprovadas entraram em vigor em janeiro de 2000 .

A política de saúde da coalizão rosa/verde diferencia-se da conservadoraliberal, contudo, apresenta certa ambivalência. Por um lado, cria incentivos para uma atenção de melhor qualidade, mais voltada para a atenção integral dos pacientes. Por outro lado, intensifica a contenção, estabelecendo controles de gastos para todos os setores (Deppe, 2000).

A nova legislação reiterou o princípio de estabilização das taxas de contribuição para a evolução das receitas do Seguro Social de Doença, condicionando-a ao ritmo de crescimento da massa salarial de contribuiçāo, o que contradiz proposiçōes social-democratas anteriores que defendiam acoplar a evolução das receitas à dinâmica de desenvolvimento da economia como um todo (PNB). A definição de um teto global (Globalbudget) com estas características garantiria uma evolução de despesas do GKV par i passu ao crescimento da riqueza da nação, além de permitir realocar recursos entre os setores de atenção. O controle de evolução das receitas passou a ser feito de modo permanente por meio da definição de tetos máximos de gastos para cada um dos setores de atenção, mecanismo até então restrito a algumas áreas e por prazos curtos.

306 Os médicos das Caixas realizaram inclusive um dia de paralisação ainda em dezembro de 1998. 
Embora não tenha ocorrido completa ruptura com a política de contenção levada a cabo até então, tendo-se reafirmado a necessidade de controle de gastos, a coalizão governamental rosa/verde, todavia, redirecionou o processo, centrando suas medidas em mudanças na organização da atenção, de modo a enfrentar problemas da oferta e estrutura da atenção.

Diversas inovações na organização da atenção, com o intuito de torná-la mais efetiva, são introduzidas. Busca-se redirecionar a assistência no sentido de uma atenção integrada, voltada para os pacientes, na qual as ações preventivas adquirem maior relevância, paralela a incentivos ao exercício de uma medicina com base em evidências. A geração de redes integradas de atenção é incentivada e promove-se a articulação dos setores ambulatorial e hospitalar. A posição dos clínicos gerais no processo de atenção é fortalecida por meio de diversas medidas. No setor hospitalar, expande-se o sistema de pagamentos por procedimentos e regulamenta-se a contra-referência (Quadro 8).

Com a política de saúde social-democrata/verdes, a posição das Caixas frente a prestadores e produtores de insumos é fortalecida. Altera-se a tradicional assimetria de poder caracterizada pela dominância dos prestadores, em particular os médicos. As Associações de Médicos das Caixas deixam de ter o monopólio na definição de toda e qualquer modalidade de atenção ambulatorial e os clínicos gerais (Hausarzt) passam a ter maior autonomia ao interior dessas associações. $\mathrm{Na}$ assistência farmacêutica, derivada da definição pela lei de uma 'lista positiva' para medicamentos, a posição das Caixas é reforçada frente à indústria farmacêutica, forte opositora deste tipo de medida.

A competição ao interior do sistema é modificada. Com a possibilidade de organização de novos modelos assistenciais e contratos diferenciados com prestadores, estimula-se a competição pelo lado da oferta de serviços. Por sua vez, a competição entre as Caixas poderá aumentar em decorrência da possibilidade de opçōes dos contribuintes por redes de atenção diferenciadas. A situação financeira das Caixas da região oriental será melhorada por meiò de transferências da região ocidental decorrentes da unificação progressiva (2001-2007) da compensação financeira da estrutura de riscos, até então separada entre as regiōes ocidental e oriental. ${ }^{307}$ Favorece-se a posição do seguro social, sendo reduzidas vantagens competitivas dos seguros privados e melhorada a proteção de beneficiários idosos do seguro privado.

307 Estima-se transferências de até 5 bilhões de marcos para região oriental. 


\section{Quadro 9 - Lei da Reforma do Seguro Social de Doença 2000 (GKV-Gesundheitsreformgesetz 2000 e Gesetz zur Rechtsangleichung in der gesetzlichen Krankenversicherung) - Principais Medidas}

\begin{tabular}{|c|c|c|}
\hline Dimensōes & Medidas & Objetivos \\
\hline Financiamento & $\begin{array}{l}\text { Definição de tetos orçamentários por setor (ambulatorial, hospitalar, } \\
\text { reabilitação, assistência farmacêutica, outros métodos tcrapćuticos, } \\
\text { clínica de restabelecimento), crescimento de gastos acoplado a taxas } \\
\text { médias - definidas em lei - de evoluçâo das receitas de contribuição } \\
\text { (massa salarial); }\end{array}$ & $\begin{array}{l}\text { Estabilização das taxas de contribuição; } \\
\text { Contenção de gastos; }\end{array}$ \\
\hline RSA & $\begin{array}{l}\text { Unificação progressiva (2001-2007) da compensação financcira da es- } \\
\text { trutura de riscos - RSA - entre as regiôes ocidental e oriental; }\end{array}$ & $\begin{array}{l}\text { Melhoria da situação financeira das Caixas da } \\
\text { regiāo oriental; }\end{array}$ \\
\hline $\begin{array}{l}\text { Assistência } \\
\text { farmacêutica }\end{array}$ & $\begin{array}{l}\text { Elaboração de lista positiva de medicamentos; } \\
\text { Criação de Instituto para Prescrições Medicamentosas; }\end{array}$ & $\begin{array}{l}\text { Melhoria qualidade das prescrições; utilização } \\
\text { racional, redução de custos; }\end{array}$ \\
\hline $\begin{array}{l}\text { Organização do } \\
\text { sistema de atenção }\end{array}$ & $\begin{array}{l}\text { Criação de redes integradas de atenção envolvendo prestadores } \\
\text { ambulatoriais, hospitais e unidades de reabilitação (managed care); } \\
\text { incentivo à utilização das redes pelos segurados mediante bônus; } \\
\text { experimentação de novos modelos de organização da atenção sem } \\
\text { o consentimento prévio das Kvens; } \\
\text { Incentivos à Atenção por clínico-geral (Hausarzt): contra-refcrência } \\
\text { obrigatória para o clínico geral; bônus para pacientes que se dispo- } \\
\text { nham a procurar outros prestadores somente quando encaminha- } \\
\text { dos pelo clínico; } \\
\text { Criação de Comissão de Clínicos Gerais ao intcrior das Associações } \\
\text { de Médicos das Caixas (Kven); separação da remuneração ambula- } \\
\text { torial distribuída por essas associações em geral e especializada; }\end{array}$ & $\begin{array}{l}\text { Contenção de custos; aumento da com- } \\
\text { petição entre prestadores; atenção inte- } \\
\text { grada ao paciente; } \\
\text { redução da assimetria de poder entre Caixas } \\
\text { e prestadorcs (quebra de monopólio das } \\
\text { Associaçōes de Médicos das Caixas); for- } \\
\text { talccimento da posição do clínico gcral } \\
\text { como coordenador da atenção ao paciente; } \\
\text { prioridade 'atenção primária'; } \\
\text { Estímulo à criação de porta de entrada; }\end{array}$ \\
\hline $\begin{array}{l}\text { Credenciamentos } \\
\text { de médicos }\end{array}$ & $\begin{array}{l}\text { Credenciamentos regulados por critérios de necessidade, segundo } \\
\text { relação } \mathrm{n}^{2} \text { médicos/ } \mathrm{n}^{2} \text { segurados; }\end{array}$ & Racionalização da oferta; \\
\hline $\begin{array}{l}\text { Controle de contas } \\
\text { ambulatoriais }\end{array}$ & $\begin{array}{l}\text { Redução de limiares de ultrapassagem de orçamentos ( } 15 \% \text { para } 5 \%) \\
\text { para auditoria das contas de consultórios e para devolução de remu- } \\
\text { neração a mais por parte dos médicos ( } 25 \% \text { para } 15 \%) \text {; }\end{array}$ & Controle de gastos; \\
\hline
\end{tabular}


Q Quadro 9 - Lei da Reforma do Seguro Social de Doença 2000 - Principais Medidas (cont.)

\begin{tabular}{|c|c|c|}
\hline Dimensões & Medidas & Objetivos \\
\hline Atenção hospitalar & $\begin{array}{l}\text { Generalização do sistema de pagamento por proccdimentos (DRG-Diagnosis } \\
\text { Related Groups); maior rigidez no controle de gastos; catálogo de cirurgias } \\
\text { ambulatoriais acordado entrc Associaçôes de Médicos e Hospitais; }\end{array}$ & Eficiência; controle de gastos; \\
\hline Prevenção & $\begin{array}{l}\text { Obrigatoriedade das Caixas em prover medidas de prevenção primária e de } \\
\text { atuação nos locais de trabalho; ampliaçăo de medidas de profilaxia da cá- } \\
\text { rie dentária; apoio a grupos de auto-ajuda; }\end{array}$ & $\begin{array}{l}\text { Melhora do estado de saúde; reintrodução } \\
\text { de açốes preventivas abolidas } \mathrm{cm} 1996 \text {; }\end{array}$ \\
\hline $\begin{array}{l}\text { Qualidade das } \\
\text { ações }\end{array}$ & $\begin{array}{l}\text { Obriga prestadores a garantir qualidade de resultados dos serviços prestados } \\
\text { e acompanhar desenvolvimento científico e tecnológico; } \\
\text { Comissão Federal de Médicos e Hospitais definirá critérios para garantia } \\
\text { de qualidade; cria Comissão Federal de Hospitais responsável pela avaliação } \\
\text { de novos métodos diagnósticos e terapêuticos e sua incorporação ao catá- } \\
\text { logo de açóes GKV; cria Grupo de Trabalho para Promoção da Garantia } \\
\text { de Qualidade da Atenção Médica com a participação das organizaçōes de } \\
\text { prestadores e seguros, e uma Comissão de Coordenação com a incumbência } \\
\text { de elaborar protocolos para diagnóstico e tratamento de enfermidades; }\end{array}$ & $\begin{array}{l}\text { Garantia dc qualidade; controle de } \\
\text { prestadores; } \\
\text { Promover 'medicina baseada cm evidências'; }\end{array}$ \\
\hline Reabilitação/Kur & $\begin{array}{l}\text { Flexibilização dos tempos máximos de internação para prevenção e reabi- } \\
\text { litaçáa; Reconhecimento das medidas de treinamento e de educação de pa- } \\
\text { cientes como reabilitação; Aumentos dos subsídios financeiros diários para } \\
\text { crianças com doenças crônicas e elevação dos tempos de internação para } \\
\text { prevenção para } 4 \text { a } 6 \text { semanas; inclusão dos gastos dos pacientes com co- } \\
\text { pagamento cm rcabilitação no limites de acometimento da renda familiar; }\end{array}$ & $\begin{array}{l}\text { Melhoria proteção crianças com doenças } \\
\text { crônicas; } \\
\text { Desonerar pacientcs; }\end{array}$ \\
\hline $\begin{array}{l}\text { Assistência } \\
\text { psiquiátrica }\end{array}$ & $\begin{array}{l}\text { Terapias de 'socialização' incluídas no catálogo; permissão para atenção am- } \\
\text { bulatorial cm hospitais psiquiátricos ou gerais; }\end{array}$ & Desospitalização de doentes mentais; \\
\hline $\begin{array}{l}\text { Regulação scguros } \\
\text { privados }\end{array}$ & $\begin{array}{l}\text { Restriçōes para ingresso no GKV de beneficiários idosos de seguros priva- } \\
\text { dos; restriçôes para clevaçâo de prêmios de segurados com idade maior de } \\
55 \text { anos; fortalecimento da tarifa padrão do seguro privado; }\end{array}$ & $\begin{array}{l}\text { Redução competição predatória entre GKV e } \\
\text { seguros privados; melhoria da proteção de } \\
\text { beneficiários idosos do seguro privado; }\end{array}$ \\
\hline $\begin{array}{l}\text { Proteção pacientcs/ } \\
\text { Consumidores }\end{array}$ & $\begin{array}{l}\text { Criação de unidades de aconselhamento e oricntação aos pacientes/consu- } \\
\text { midores para o conjunto das Caixas. }\end{array}$ & $\begin{array}{l}\text { Redução da assimetria de informações entre } \\
\text { pacientes e prestadores. }\end{array}$ \\
\hline
\end{tabular}

Fonte: Bundestag-Drucksache 14/2369 de 15.12.1999; Bundesrat-Drucksache 732/99 e 733/99 de 16.12.1999. 
Em síntese, a Lei da Reforma do Seguro Social de Doença 2000 ( $G K V$ Gesundheitsreformgesetz 2000) fortaleceu a posição do GKV frente aos prestadores de serviços. A competição ao interior do sistema foi modificada. Ampliou-se a competiçāo, não entre Caixas, como ocorrera nas etapas anteriores da reforma, mas sim entre prestadores, em particular, no setor ambulatorial por meio da criação de redes integradas de atenção e do fortalecimento da atuação de clínicos gerais no processo de atenção. A introdução destes incentivos à concorrência pelo lado da oferta é paralela à difusão cada vez maior de mecanismos gerenciais advindos da experiência empresarial privada na gestão das Caixas provedoras de proteção social ao risco de adoecer.

Diversas das medidas introduzidas com a Lei da Reforma do GKV 2000, como apontado acima, estão direcionadas a enfrentar parte dos principais problemas do sistema de atenção e têm alguma potencialidade para tal. Como apresentado nos capítulos referentes à descrição e análise do seguro social de doença $\mathrm{e}$ setores de atenção, os problemas identificados por diversos dos atores sociais no sistema de atenção dizem respeito: à ênfase nos aspectos curativos e em sua inadequação para resolver problemas crônico-degenerativos; ao papel secundário da prevenção e promoção da saúde; às ineficiências do sistema de atenção decorrentes de estruturas inadequadas, bem como a estímulos equivocados e deficiências na garantia de qualidade; falta de integração do sistema de atenção, em especial, a não articulação entre atenção ambulatorial e hospitalar; predominância da oferta na definição da quantidade, preço e qualidade dos serviços - assimetria das relações de poder entre Caixas e prestadores, com dominância dos últimos, em particular, os médicos -; regulação insuficiente do setor farmacêutico, entre outros. Embora o conjunto de medidas não dê conta de toda a abrangência destes problemas, as modalidades de intervenção selecionadas estão mais direcionadas aos problemas da atenção do que na terceira etapa, apresentando escopo mais amplo do que os objetivos estritos de contenção.

O processo de contenção de gastos no Séguro Social de Doença encontra assim um novo equilíbrio, ponto mediano entre os princípios de subsidiariedade e solidariedade, possibilitado pela nova correlação de forças parlamentares na aprovação da lei. Contudo, somente a efetiva implementação das medidas aprovadas poderá sinalizar mudanças reais na política de saúde. 